$\frac{1}{-}$

sing

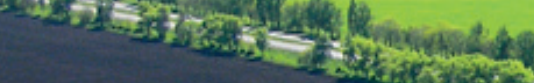

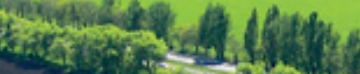

\title{
Feiten en cijfers vergroening GLB 2018
}

Berien Elbersen \& Jeroen Schutt 



\section{Feiten en cijfers vergroening GLB 2018}

Berien Elbersen \& Jeroen Schutt

Dit onderzoek is uitgevoerd door Wageningen Environmental Research in samenwerking met RVO en in opdracht van en gefinancierd door het Ministerie van Landbouw, Natuur en Voedselkwaliteit, in het kader van het Beleidsondersteunend Onderzoeksthema KD-2019-032.

Wageningen Environmental Research

Wageningen, juli 2019

Gereviewd door:

Lysander Lantain, teamcoördinator directe betalingen GLB, Ministerie van Landbouw, Natuur en Voedselkwaliteit

Akkoord voor publicatie:

Sander Jansen, teamleider van Earth Informatics team, Wageningen

Environmental Research

Rapport WENR 2963

ISSN 1566-7197 
Elbersen, B.S, Schutt, J., 2019. Feiten en cijfers vergroening GLB 2018. Wageningen, Wageningen Environmental Research, Rapport 2963. 40 blz.; 1 fig.; 4 tab.; 10 ref.

Voorliggend rapport presenteert de uitkomsten van een monitoring van de vergroening voor het jaar 2018 volgens de geactualiseerde methode en gebruikmakend van gegevens die werden verzameld in samenwerking met RVO. De evaluatie laat zien hoe en door welke boeren maatregelen voor blijvend grasland, gewasdiversificatie en ecologische aandachtsgebieden en tevens de equivalente maatregelen zijn opgepakt. De resultaten werden geïnterpreteerd wat betreft te verwachten effecten in relatie tot de gestelde doelen van de vergroening. In de analyse worden ook de resultaten uit de voorgaande monitoringsrapportage betrokken, zodat een beeld ontstaat wat de vergroening na vier jaar heeft opgeleverd.

Trefwoorden: GLB, vergroening

Dit rapport is gratis te downloaden van https://doi.org/10.18174/501131 of op www.wur.nl/environmental-research (ga naar 'Wageningen Environmental Research' in de grijze balk onderaan). Wageningen Environmental Research verstrekt geen gedrukte exemplaren van rapporten.

(C) 2019 Wageningen Environmental Research (instituut binnen de rechtspersoon Stichting Wageningen Research), Postbus 47, 6700 AA Wageningen, T 03174807 00, www.wur.nl/environmental-research. Wageningen Environmental Research is onderdeel van Wageningen University \& Research.

- Overname, verveelvoudiging of openbaarmaking van deze uitgave is toegestaan mits met duidelijke bronvermelding.

- Overname, verveelvoudiging of openbaarmaking is niet toegestaan voor commerciële doeleinden en/of geldelijk gewin.

- Overname, verveelvoudiging of openbaarmaking is niet toegestaan voor die gedeelten van deze uitgave waarvan duidelijk is dat de auteursrechten liggen bij derden en/of zijn voorbehouden.

Wageningen Environmental Research aanvaardt geen aansprakelijkheid voor eventuele schade voortvloeiend uit het gebruik van de resultaten van dit onderzoek of de toepassing van de adviezen.

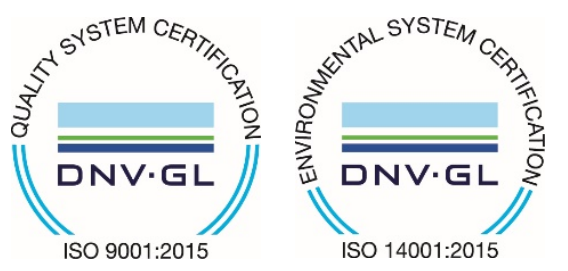

Wageningen Environmental Research werkt sinds 2003 met een ISO 9001 gecertificeerd kwaliteitsmanagementsysteem. In 2006 heeft Wageningen Environmental Research een milieuzorgsysteem geïmplementeerd, gecertificeerd volgens de norm ISO 14001.

Wageningen Environmental Research geeft via ISO 26000 invulling aan haar maatschappelijke verantwoordelijkheid.

Wageningen Environmental Research Rapport 2963 | ISSN 1566-7197 


\section{Inhoud}

$\begin{array}{ll}\text { Verantwoording } & 5\end{array}$

$\begin{array}{ll}\text { Woord vooraf } & 7\end{array}$

$\begin{array}{ll}\text { Afkortingen } & 9\end{array}$

$\begin{array}{ll}\text { Samenvatting } & 11\end{array}$

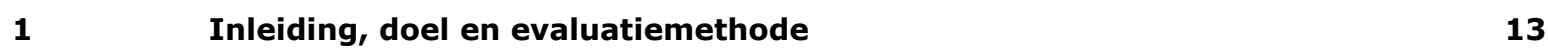

1.1 Aanleiding 13

1.2 Vergroening in het GLB $\quad 13$

1.3 Doelstellingen van vergroening in het GLB en EU-monitoring in het
Gemeenschappelijk Toezicht en Evaluatie Kader

1.4 Methode voor monitoring van vergroening in Nederlandse situatie $\quad 16$

$\begin{array}{lll}1.5 & \text { Leeswijzer } & 17\end{array}$

$2 \quad$ Resultaten van de evaluatie en monitoring van vergroening na vier jaar

$2.1 \quad$ Inleiding 18

2.2 Algemeen, gewasdiversificatie en equivalente maatregelen $\quad 18$

$\begin{array}{lll}2.3 & \text { Instandhouding blijvend grasland } & 21\end{array}$

$\begin{array}{lll}2.4 & \text { Ecologische aandachtsgebieden (EA) } & 23\end{array}$

$3 \quad$ Conclusies resultaten van vergroening na vier jaar 26

$\begin{array}{ll}\text { Literatuur } & 28\end{array}$

Bijlage 1 Invulling van vergroeningsmaatregelen in Nederland 29

Bijlage 2 Overzicht voorwaarden en wegingsfactoren voor ecologische aandachtsgebieden 2018 (Algemene lijst) 33

Bijlage 3 Overzicht output- en resultaatindicatoren voor monitoring vergroening in GLB 



\section{Verantwoording}

Rapport: 2963

Projectnummer: 5200045593

Wageningen Environmental Research (WENR) hecht grote waarde aan de kwaliteit van onze eindproducten. Een review van de rapporten op wetenschappelijke kwaliteit door een referent maakt standaard onderdeel uit van ons kwaliteitsbeleid.

Akkoord Referent die het heeft beoordeeld,

functie: $\quad$ teamcoördinator directe betalingen GLB, Ministerie van Landbouw, Natuur en Voedselkwaliteit

naam: Lysander Lantain

datum: 20 september 2019

Akkoord teamleider voor de inhoud,

naam: Sander Jansen

datum: 20 september 2019 


\section{Woord vooraf}

Dit rapport geeft antwoord op de vraag: Wat kan er na vier jaar vergroening van het GLB gezegd worden over de resultaten en de verwachte effecten?

Zoals toegezegd door het ministerie van Landbouw, Natuur en Voedselzekerheid vanwege de Motie Ouwehand, zal er jaarlijks een rapportage naar de Kamer worden gestuurd over de effecten van de vergroening van het Gemeenschappelijk Landbouw Beleid. In dit rapport worden de resultaten van de monitoring van vergroening in 2018 gepresenteerd en worden deze resultaten ook vergeleken met de uitkomsten van monitoring voor de jaren 2015, 2016 en 2017. Bij de beschrijving van de resultaten worden de belangrijkste bevindingen en aanbevelingen genoemd.

Dit rapport is gebaseerd op gegevens die RVO aanlevert aan de EU m.b.t. monitoring vergroening. Hierbij wordt uitgegaan van geconstateerde (en als deze niet beschikbaar zijn, de aangevraagde) gegevens. Het is dus een tussenstand in december 2018, op het moment dat de beoordeling van aanvragen nog gaande is.

Wij danken dhr. Lantain van de Directie ELVV van het ministerie van Landbouw, Natuur en Voedselkwaliteit voor het voorleggen van deze vraag bij ons en voor de begeleiding. Wij danken Herman Blom voor de aanlevering van de RVO-data en de geduldige en gedegen controle op alle data en tekst in dit rapport. 


\section{Afkortingen}

\begin{tabular}{ll}
\hline Afkorting & Toelichting \\
BG & Blijvend grasland \\
\hline EA & Ecologisch Aandachtsgebied \\
\hline EKBG & Ecologisch Kwetsbaar Blijvend Grasland \\
\hline GLB & Gemeenschappelijk Landbouw Beleid \\
\hline GTEK & Gemeenschappelijk Toezicht en Evaluatie Kader \\
\hline HNV & High Nature Value farmland \\
\hline
\end{tabular}




\section{Samenvatting}

In dit rapport worden de resultaten van de monitoring van de vergroeningsmaatregelen in 2018 gepresenteerd en worden deze vergeleken met die van 2015-2017. Deze jaarlijkse rapportage is toegezegd door het ministerie van Landbouw, Natuur en Voedselzekerheid vanwege de Motie Ouwehand, die voorschrijft dat er jaarlijks een rapportage naar de Kamer zal worden gestuurd over de effecten van de vergroeningsmaatregelen van het Gemeenschappelijk Landbouw Beleid.

De vergroeningsmaatregelen werden in de hervorming van 2013 geïntroduceerd (EC COM 1307/2013) en traden in januari 2015 in werking. De vergroeningsmaatregelen beslaan $30 \%$ van de directe inkomenssteun aan landbouwbedrijven en bestaan uit:

1. Gewasdiversificatie toepassen, hetgeen een minimum aan verschillende gewassen op een bedrijf in stand houden betekent.

2. Een minimum aan ecologische aandachtsgebieden (EA) in stand houden.

3. Het in stand houden van blijvend grasland (het aandeel blijvend grasland mag landelijk niet meer dan $5 \%$ dalen en voor kwetsbare graslanden geldt een ploegverbod (bijvoorbeeld blijvend gras binnen Natura 2000-gebieden).

In Nederland waren tot 2016 twee equivalente pakketten met een duurzaamheidscertificaat mogelijk die als alternatief konden worden ingezet voor de generieke vergroeningsmaatregelen. Het gaat hierbij om het akkerbouw-strokenpakket en het pakket Veldleeuwerik, waarbij het alternatief ziet op de invulling van de Ecologische Aandachtsgebieden-verplichting. Vanaf 2016 kunnen boeren voor het pakket Vezelhennep ook een duurzaamheidscertificaat ontvangen.

De vergroeningsmaatregelen hebben in Nederland een grote reikwijdte en deze is tussen 2015 en 2018 ook toegenomen. In 2015 had 67\% van de boeren ten minste één vergroeningsverplichting en in 2018 was dit gestegen naar 74\%. De landbouwgrond die bij deze vergroeningsplichtige bedrijven hoort, bedroeg $90 \%$ in 2015 en $92 \%$ in 2018. Gesteld kan worden dat Nederland hiermee hoog scoort in Europees perspectief, waar het gemiddelde percentage landbouwgrond dat ten minste onder één verplichting valt op 73 ligt (Europese Rekenkamer 2017).

Dit hoge percentage landbouwgrond met ten minste één vergroeningsverplichting wil echter niet zeggen dat er door de vergroening veel is veranderd in de landbouwpraktijk op bedrijven.

Ten eerste omdat dit percentage inclusief alle bedrijven is met een instandhoudingsverplichting voor blijvend grasland (62\% van de bedrijven in Nederland). De grote meerderheid van deze bedrijven moet haar areaal blijvend gras rapporteren, maar hoeft om de vergroeningspremie te ontvangen geen aanvullende maatregelen te treffen, tenzij ze blijvend grasland heeft gelegen binnen Natura 2000-gebied. Dit geldt zolang de daling van het relatief areaal blijvend grasland in het totale landbouwareaal niet meer dan 5\% bedraagt ten opzichte van het referentiejaar 2012. In 2018 was er sprake van een relatieve toename met $0,7 \%$ in dit areaal. Voor $6 \%$ van de boeren met blijvend grasland in Natura 2000-gebieden geldt een omzet- en ploegverbod. Het totaal van blijvend grasland met dit verbod, het zogenaamd Ecologisch Kwetsbaar Blijven Grasland (EKBG), is toegenomen t.o.v. voorgaande jaren en bedraagt in 201842.428 ha en dit betreft $6 \%$ van het totaal areaal blijvend grasland in Nederland. Daarbij moet wel de kanttekening worden gemaakt dat Nederland $100 \%$ van het blijvend grasland areaal binnen Natura 2000 heeft aangewezen als kwetsbaar. Dit komt neer op een areaal van 56.194 ha (7\% van het totale blijvend grasland areaal). Slechts een deel van dit gebied valt onder het beheer van vergroeningsplichtige boeren en verklaart het grote verschil tussen aangewezen hectare EKBG en opgegeven hectare onder vergroening.

Ten tweede komt gewasdiversificatie over het algemeen overeen met de gangbare landbouwpraktijk en voegt daardoor weinig toe. Tussen 2015 en 2018 steeg het aandeel boeren dat zich hieraan moet houden van 22 naar 24\%, maar in de praktijk heeft de maatregel niet tot meer diversiteit in gewassen 
geleid. Het gemiddeld aantal hoofdgewassen per bedrijf is zelfs afgenomen sinds 2015 (Elbersen et al., 2018).

Ten derde wordt de maatregel voor Ecologische Aandachtsgebieden (EA) op een beperkt areaal toegepast, namelijk op $12 \%$ van het landbouwareaal.

Het merendeel van de boeren in Nederland heeft, net als in voorgaande jaren, gekozen voor productie-gerelateerde EA als vanggewassen en stikstofbindende gewassen. Deze gewassen leveren wel een positieve bijdrage aan bodemkwaliteit, maar dragen niet bij aan het verbeteren van de biodiversiteit, terwijl de EA-maatregel daar oorspronkelijk wel voor bedoeld was.

Voor zowel het vastleggen van bodemkoolstof als het beschermen van onder- en bovengrondse biodiversiteit is het in stand houden van blijvend grasland belangrijk. De vergroeningsmaatregelen vanuit het GLB voor de bescherming van blijvend grasland lijken ontoereikend, omdat het areaal blijvend gras een dalende trend laat zien tot 2017. Echter in 2018 is er een omslag en is het areaal blijvend grasland met $0,7 \%$ toegenomen ten opzichte van het referentiejaar 2012. Binnen Natura 2000-gebieden geldt een ploeg- en omzetverbod voor blijvend gras (op $7 \%$ van het permanente grasareaal). Bescherming van blijvend gras (tegen scheuren en omzetten) geldt echter niet voor een groot deel van de weidevogel- en veenweidegebieden die vaak overlappen met zogenaamde 'High Nature Value farmlands', omdat die buiten Natura 2000 liggen. Echter scheuren en omzetten van deze graslanden brengen risico's mee voor zowel de biodiversiteit als voor het vasthouden van de bodemkoolstof.

Kortom, de meerwaarde die vergroening heeft op verbetering van de bijdrage die het Gemeenschappelijk Landbouw Beleid (GLB) aan EU-brede milieu- en klimaatdoelen heeft, is zeer beperkt gebleken. Dit sluit aan bij de conclusies die de Europese Rekenkamer (2017) ook heeft getrokken na evaluatie van vergroening op EU-niveau. 


\section{Inleiding, doel en evaluatiemethode}

\section{$1.1 \quad$ Aanleiding}

De vergroeningsmaatregelen binnen de $1^{\mathrm{e}}$ pijler van het Europese Gemeenschappelijk Landbouw Beleid werden in de hervorming van het GLB van 2013 geïntroduceerd (EC COM 1307/2013) en traden in januari 2015 in werking. In de vergroening moeten drie generieke maatregelen ervoor zorgen dat de milieuprestaties van individuele agrarische bedrijven omhooggaan. Ze werden bij de invoering in 2013 gezien als een belangrijk instrument voor verduurzaming van de Europese landbouw en daarmee ook van de Nederlandse.

In Van Doorn (et al., 2015) is een systematiek voor monitoring en evaluatie vergroening op nationaal niveau uitgewerkt. De systematiek is vervolgens toegepast met een nulmeting in 2015 en ondertussen ook met een voortgangsmeting voor 2016 (Van Doorn en Smidt, 2017) en 2017 (Elbersen et al., 2018). In dit rapport worden de resultaten van de monitoring van vergroening in 2018 gepresenteerd en worden deze resultaten ook vergeleken met de uitkomsten van monitoring voor de jaren 2015, 2016 en 2017 (Elbersen et al., 2018), waardoor een totaaloverzicht ontstaat van de resultaten van implementatie van de vergroening over een periode van vier jaar. De resultaten kunnen gebruikt worden voor de verdere uitwerking van het GLB na 2020 en voor de jaarlijkse rapportage naar de Tweede Kamer over de effecten van de vergroening van het Gemeenschappelijk Landbouw Beleid, welke is toegezegd vanwege de Motie Ouwehand.

\subsection{Vergroening in het GLB}

De vergroening bestaat uit een koppeling van vergroeningsmaatregelen aan uitbetaling van $30 \%$ van de directe inkomenssteun aan landbouwbedrijven. Dit betekent dat boeren verplicht zijn vergroeningsmaatregelen toe te passen op hun bedrijf om de $30 \%$ vergroeningspremies te ontvangen boven op de basispremie.

De vergroeningsverplichtingen bestaan uit:

1. Gewasdiversificatie toepassen, hetgeen een minimum aan verschillende gewassen op een bedrijf in stand houden betekent.

2. Een minimum aan ecologische aandachtsgebieden (EA) in stand houden.

3. Het in stand houden van blijvend grasland (het aandeel blijvend grasland mag landelijk niet meer dan $5 \%$ dalen en voor kwetsbare graslanden geldt een ploegverbod (bijvoorbeeld blijvend gras binnen Natura 2000-gebieden).

Naast vergroeningsverplichtingen, zoals hierboven genoemd en waarop deze monitoring betrekking heeft, zijn er ook andere milieugerichte maatregelen in het kader van het GLB waar de boer zich aan moet houden of vrijwillig aan kan voldoen (Zie ook Elbersen et al., 2018; hoofdstuk 1, paragraaf 1.2). Deze milieugerichte maatregelen zijn:

1. De 'randvoorwaarden' van het GLB (in het Engels aangeduid als 'Cross-Compliance') waar een boer zich verplicht aan dient te houden.

2. De maatregelen die de boer vrijwillig kan kiezen, worden vergoed vanuit Pijler 2 van het GLB (Plattelandsprogramma. In Nederland omvatten deze vooral de agrarische natuurbeheermaatregelen waarvoor collectieven van boeren beheerovereenkomsten moeten afsluiten als collectief. In tegenstelling tot de vergroeningsmaatregelen die van toepassing zijn op een ruime meerderheid van agrariërs en daarbij behorend landbouwareaal, hebben vrijwillige matregelen onder Pijler 2 een veel kleinere invloed op het landbouwareaal in Nederland. 
Vergroening is niet verplicht voor alle boeren:

- Biologische bedrijven zijn uitgezonderd van vergroening, omdat deze al worden beschouwd als groen genoeg ('green by definition').

- Bedrijven met een bedrijfsareaal van minder dan 15 ha zijn vrijgesteld van het toepassen van de vergroeningsmaatregel Ecologische Aandachtsgebieden.

- Bedrijven met minder dan 10 ha bouwland hoeven geen gewasdiversificatie toe te passen.

- Boeren die een vergroeningsverplichting hebben, kunnen ook kiezen voor equivalente maatregelen. In Nederland zijn hiervoor equivalente pakketten ingevoerd die een duurzaamheidscertificaat hebben gekregen van het ministerie van LNV. In 2015 konden boeren kiezen voor twee equivalente maatregelen in 2015: het Akkerbouwstrokenpakket en het pakket Veldleeuwerik en is er in 2016 nog een pakket Vezelhennep bijgekomen (zie Bijlage I voor meer uitleg over deze pakketten).

In de volgende paragraaf worden meer details gegeven over de minimale drempelwaarden voor vergroening en de nationale invulling per type vergroeningsmaatregel.

Uitgaven aan vergroening bedragen 30\% van Pijler 1-uitgaven. Voor de directe betalingen is het budget in 2015, 2016, 2017 en 2018 respectievelijk 749 mln., 737 mln., 724 mln. en 683 mln. euro, dus afnemend. Daarvan is $30 \%$ beschikbaar voor vergroening, wat neerkomt op respectievelijk $225 \mathrm{mln} ., 221 \mathrm{mln} ., 217 \mathrm{mln}$. en $205 \mathrm{mln}$. euro in 2015, 2016, 2017 en 2018.

De EU-uitgaven aan vergroening zijn dus groot, zowel in Nederland als op EU-niveau. De European Court of Auditors (2017) heeft berekend dat $8 \%$ van het totale EU-budget in de EU aan vergroening wordt uitgegeven.

De EC-verordening (EC COM 1307/2013) biedt ruimte aan de lidstaten om de vergroeningsmaatregelen nationaal verder in te vullen. Daarom heeft Nederland zijn nationale invulling van de vergroening in 2014 vastgesteld in Kamerbrieven van toenmalig staatssecretaris Dijksma (Kamerbrieven van resp. 6-12-2013, 6-6-2014 en 29-7-2014). In haar brief aan de Tweede Kamer van 6-12-2013 worden vergroeningsmaatregelen gekoppeld aan de doelstellingen van 'een goede agrobiodiversiteit, milieukwaliteit en bescherming van het klimaat'. In Bijlage 1 wordt uitgelegd hoe vergroening nationaal is ingevuld voor de drie vergroeningsverplichtingen.

\subsection{Doelstellingen van vergroening in het GLB en EU- monitoring in het Gemeenschappelijk Toezicht en Evaluatie Kader}

De vergroening heeft als belangrijkste doelstelling het verbeteren van de algehele milieuprestatie (environmental performance) van een agrarisch bedrijf, waarbij het specifiek gaat om verbetering van de biodiversiteit, de bodem- en waterkwaliteit en het verminderen van broeikasgassen (EC COM 1307/2013). Bovendien zijn deze milieudoelstellingen specifieker geformuleerd per type vergroeningsmaatregel (zie Kader 1). Zo heeft de invoering van de Ecologische Aandachtsgebieden (EA's) primair als doelstelling het verbeteren van de biodiversiteit, terwijl het in stand houden van blijvend grasland een bredere, algehele milieuprestatie dient, maar ook een specifieke, namelijk het vastleggen van koolstof ten behoeve van het klimaat (zie Kader 1). 
Kader 1: Specifieke milieudoelstellingen van vergroeningsmaatregelen (EC COM 1307/2013):

Ecological focus areas 'should be established, in particular, in order to safeguard and improve biodiversity on farms. The ecological focus area should therefore consist of areas directly affecting biodiversity such as land lying fallow, landscape features, terraces, buffer strips, afforested areas and agro-forestry areas, or indirectly affecting biodiversity through a reduced use of inputs on the farm, such as areas covered by catch crops and winter green cover' (Reg. 1307/2013, EC, 2013).

As to permanent grasslands (PGs) the Regulation 1307/2013 specifies that these should be 'maintained for the sake of the environmental benefits of permanent grassland and in particular carbon sequestration'. 'This protection should consist of a ban on ploughing and conversion on the environmentally most sensitive areas in "Natura 2000" areas covered by Directives 92/43/EEC and 2009/147/EC, and of a more general safeguard, based on a ratio of permanent grassland, against conversion to other uses. Member States should be empowered to delineate further environmentally sensitive areas not covered by those Directives. In addition, they should choose at which territorial level the ratio should apply' (Reg. 1307/2013, EC, 2013).

Voor het meten van resultaten en effecten van invoering van het GLB, is er een Gemeenschappelijk Toezicht en Evaluatie Kader (GTEK) ontwikkeld. Dit GTEK wordt gebruikt om de effecten van GLBmaatregelen zoals in de lidstaten toegepast, te monitoren op effecten. Dit GTEK is dus ook van toepassing op vergroening. Invoering van het GTEK is primair gericht op het toetsen van het halen van de GLB-doelstellingen. De vergroeningsmaatregelen zijn met name te koppelen aan de tweede algemene doelstelling van het GLB en dat is 'duurzaam beheer van natuurlijke hulpbronnen en klimaataanpak'.

In het GTEK worden verschillende typen doelstellingen van het GLB gekoppeld aan verschillende typen indicatoren. Een onderscheid wordt gemaakt in effectindicatoren, resultaatindicatoren en outputindicatoren. Voor vergroening (ingevoerd vanaf januari 2015) zijn aan het GTEK verschillende effect-, resultaat- en outputindicatoren toegevoegd die de voortgang en effecten van dit nieuwe beleid moeten meten.

De effectindicatoren meten in hoeverre de algemene doelstellingen van het GLB gehaald worden; in het geval van vergroening gaat het dan om de bijdrage van GLB aan duurzaam beheer van natuurlijke hulpbronnen en klimaataanpak en specifieke effectindicatoren hiervoor in het GTEK gaan over ontwikkeling in populaties boerenlandvogels, uitstoot van broeikasgassen, waterkwaliteit, organischestofgehalte in de bodem, bodemerosie en areaal boerenland met hoge natuurwaarde (zogenaamde High Nature Value farmland).

Resultaatindicatoren meten de directe effecten van een beleidsmaatregel. Bij vergroening wordt dan met resultaatindicatoren veel meer gemeten wat de directe uitkomsten zijn van de implementatie van de maatregelen. Voorbeelden van dergelijke indicatoren zijn het aandeel landbouwareaal dat onder vergroeningsmaatregelen valt, het aandeel EA in het landbouwareaal en het aandeel blijvend grasland in het totaalareaal.

Outputindicatoren meten de toepassing van maatregelen en instrumenten. Voor vergroening zijn vanaf 2015 verschillende outputindicatoren toegevoegd aan het GTEK die te koppelen zijn met de separate vergroeningsmaatregelen, namelijk aantal boeren met vergroeningmaatregelen, areaal EA, areaal met gewasdiversificatie en areaal blijvend grasland.

$\mathrm{Na}$ vier jaar vergroening is er een aantal studies uitgevoerd naar de resultaten van de vergroening voor de gehele EU. De uitkomsten van deze studies worden uitgebreid besproken in Elbersen (et al., 2018).

Een korte opsomming van de belangrijkste conclusies over vergroening die uit de inventarisatie door Elbersen (et al., 2018) voortkomt, volgt hier: 
- Ten aanzien van de vergroeningsmaatregelen gewasdiversificatie en EA-verplichting wordt geconcludeerd door Hart (2015) en de Europese Rekenkamer (2017) dat het areaal bouwland dat onder een vergroeningsverplichting valt, in veel landen veel lager uitvalt dan oorspronkelijk met de invoering van de EU-maatregel bedoeld was. Dit lage percentage heeft verschillende oorzaken, waarvan de belangrijkste het zogenaamde 'deadweight'-effect is, waarmee wordt bedoeld dat veel boeren al voldeden aan de vergroeningseisen voordat de maatregelen in 2015 van kracht werden. Daarnaast is veel land niet onder de gewasdiversificatie en/of EA-verplichting gaan vallen vanwege de vele uitzonderingsregels, die maken dat een groot deel van de boeren niet mee hoeft te doen.

- Over gewasdiversificatie constateerde de Europese Rekenkamer (2017) al dat dit op 1\% van het agrarisch areaal tot een verandering in landgebruik leidt en dat de potentiële milieubijdrage bij lange na niet wordt gehaald.

- Ten aanzien van de nationale implementatie van de aanwijzing van blijvend-graslandgebieden met ploeg- en omzetverbod geeft de Europese Rekenkamer (2017) aan dat deze gebieden alleen zijn aangewezen ter bescherming van biodiverse graslanden, waardoor de aanwijzing grotendeels beperkt is gebleven tot graslandgebieden in Natura 2000-gebieden. De doelstelling van vastlegging van bodemkoolstof wordt echter nauwelijks met de maatregel bediend, terwijl deze maatregel wel aan de EU-doelstelling moet bijdragen.

- De Rekenkamer benadrukt ook dat blijvend graslandareaal in de EU toch al sterker is teruggelopen dan $5 \%$ in de laatste 10 jaar, maar dat deze terugloop door verandering in referentiejaar en terugloop in totaal landbouwareaal is gecamoufleerd in de officiële monitoringcijfers. Zo werd in de periode 2007-2014 een graslandreferentieratio gebruikt dat 1,5\% lager ligt dan het nieuw bepaalde graslandreferentieniveau van 2016. Dit verschil camoufleert dat de terugloop in blijvend grasland in de EU tussen 2007 en 2016 in het echt met 7,7\% afnam (= afname van 3 miljoen ha). Het betekent ook volgens de Rekenkamer (2017) dat monitoring van het blijvend-graslandareaal op nationaal niveau, zoals in de grote meerderheid van EU-landen wordt gedaan, niet voldoende effectief is om verlies van bodemkoolstof via graslandomzetting tegen te gaan.

De hierboven genoemde uitkomsten van evaluatiestudies zijn gebaseerd op EU-brede data en hoeven niet (volledig) te gelden voor de Nederlandse situatie. Daarom worden de resultaten van de evaluatie van vergroening voor Nederland over 2018 in het volgende hoofdstuk ook zo nu en dan vergeleken met de situatie in andere EU-landen. Bovendien zullen de conclusies in hoofdstuk 3 van deze studie, net als in de voorgaande studie (Elbersen et al., 2018), ook in het licht worden geplaatst van de hierboven besproken uitkomsten van de evaluatiestudie van de Europese Rekenkamer (2017).

\subsection{Methode voor monitoring van vergroening in Nederlandse situatie}

Een methode voor monitoring van vergroening in Nederland werd in 2015 (Van Doorn et al., 2015) al uitgewerkt. De hier gepresenteerde studie volgt de methode die door Van Doorn (et al., 2015) werd uitgewerkt, zodat de resultaten van deze studie ook met die van voorgaande jaren vergeleken kunnen worden. Hierdoor kan ook een totaaloverzicht gepresenteerd worden in dit rapport van de resultaten van de vergroening over een periode van vier jaar.

Het Gemeenschappelijk Toezicht en Evaluatie Kader (GTEK) is door de invoering van vergroening al uitgebreid vanaf 2015 met specifieke effect-, resultaat- en outputindicatoren. Deze zijn bedoeld om het vergroeningsbeleid te monitoren op voortgang en effecten. Voortbouwend op deze indicatoren hebben Van Doorn et al. (2015) een raamwerk ontwikkeld voor nationale monitoring van vergroening. Deze moet inzicht bieden in de uitkomsten van vergroening in de specifieke Nederlandse situatie, maar ook toeleverend zijn voor de Europese monitoring, waarvoor Nederland ook informatie moet aanleveren aan de Europese Commissie.

Bij de ontwikkeling van het monitoringraamwerk voor vergroening voor de Nederlandse situatie, hebben Van Doorn et al. (2015) de vergroeningsindicatoren in het GTEK als uitgangspunt genomen. De GTEK-indicatoren zijn vervolgens verder uitgewerkt voor de Nederlandse situatie, waarbij rekening is gehouden met de nationale keuzes voor vergroening en de relevantie van vergroening voor 
Nederland, de kosteneffectiviteit door zo veel mogelijk gebruik te maken met bestaande gegevensbestanden en de mogelijkheid van gebruik van meer ruimtelijk expliciete data (als die voorhanden zijn).

Het indicatorraamwerk Van Doorn et al. (2015) wordt dus in deze monitoringstudie opnieuw toegepast en een overzicht van de output- en resultaatindicatoren is te vinden in Bijlage 3 van dit rapport.

\subsection{Leeswijzer}

In dit eerste hoofdstuk zijn de achtergronden van de studie beschreven, is uitgelegd wat het actuele vergroeningsbeleid in de praktijk inhoudt en met welke systematiek de monitoring en evaluatie van vergroening in de Nederlandse situatie wordt uitgevoerd. In het hiernavolgende hoofdstuk worden de resultaten van de monitoring en evaluatie van vergroening voor 2018 gepresenteerd en vergeleken met die voor de jaren 2015 t/m 2017. Dit rapport wordt afgesloten met hoofdstuk 3, waarin de belangrijkste conclusies staan over de trendanalyse 2015-2018 met betrekking tot de resultaten van vergroening. 


\section{Resultaten van de evaluatie en monitoring van vergroening na vier jaar}

\section{$2.1 \quad$ Inleiding}

In het hiernavolgende hoofdstuk worden de resultaten van de monitoring en evaluatie van vergroening voor 2018 gepresenteerd en vergeleken met voorgaande jaren 2015, 2016 en 2017. Hierdoor ontstaat een trendanalyse van de resultaten van vergroening in de laatste vier jaar.

Allereerst zal in paragraaf 2.2 een overzicht volgen van deelname in vergroeningsmaatregelen, equivalente maatregelen en vrijstellingen van vergroening. In paragraaf 2.3 worden beheer van blijvend grasland en toepassing van ploeg- en omzetverbod in blijvende kwetsbare graslandgebieden besproken. Tot slot gaat paragraaf 2.4 over de toepassing van EA's. De vergroeningsmaatregelen worden in dit hoofdstuk allemaal gemonitord op basis van de indicatoren zoals door Van Doorn (et al., 2015) ontwikkeld en waarvoor een overzicht ook in Bijlage 3 van dit rapport is opgenomen.

\subsection{Algemeen, gewasdiversificatie en equivalente maatregelen}

Over de onderzoeksperiode $2015-2018$, is het totaal aantal landbouwbedrijven met $16 \%$ gedaald, van 63.910 naar 53.780. Het totaalaantal landbouwbedrijven daalt sneller dan het aantal dat zich aan ten minste één vergroeningsmaatregel moet houden. Dit betekent ook dat het aantal landbouwbedrijven dat zich hieraan moet houden relatief is toegenomen: van $78 \%$ in 2015 naar $83 \%$ in 2018 . Het areaal landbouwgrond dat ten minste onder één vergroeningsverplichting valt, is in absolute en relatieve zin gestegen.

In areaal heeft de vergroening een relatief grote reikwijdte (van 92\%) in Nederland in 2018.

Echter, dit getal moet om twee redenen voorzichtig worden geïnterpreteerd. Ten eerste omdat $82 \%$ van dit vergroeningsareaal bij bedrijven hoort die zich aan de instandhouding van blijvend grasland moeten houden. Omdat het blijvend grasland areaal niet is gedaald t.o.v. het referentieratio blijvend grasland (zie Tabel 2), hoeven boeren met blijvend grasland geen enkele concrete actie te ondernemen om zich aan de vergroeningsverplichting te houden. Ten tweede omdat op slechts een beperkt deel van dit vergroeningsareaal sprake is van verandering in landbouwpraktijk, zoals zal blijken uit de gedetailleerde analyse van de EA-gebiedenverplichting in paragraaf 2.4 .

Wel kan men concluderen dat Nederland een relatief groot areaal heeft dat onder vergroening valt. In Nederland ligt dit in 2018 op 92\% en het Europese gemiddelde lag op 73\% van het landbouwareaal (Europese Rekenkamer 2017).

De relatieve en absolute stijging in vergroeningsareaal tussen 2015 en 2018 is overigens wel voornamelijk veroorzaakt door bedrijven die zich aan instandhouding blijvend grasland moeten houden. Opvallend is dat tussen 2015 en 2018 het landbouwareaal behorend bij deze bedrijven duidelijk meer is toegenomen (5\%) dan het totaalareaal van alle landbouwbedrijven in dezelfde periode (zie Tabel 1). 


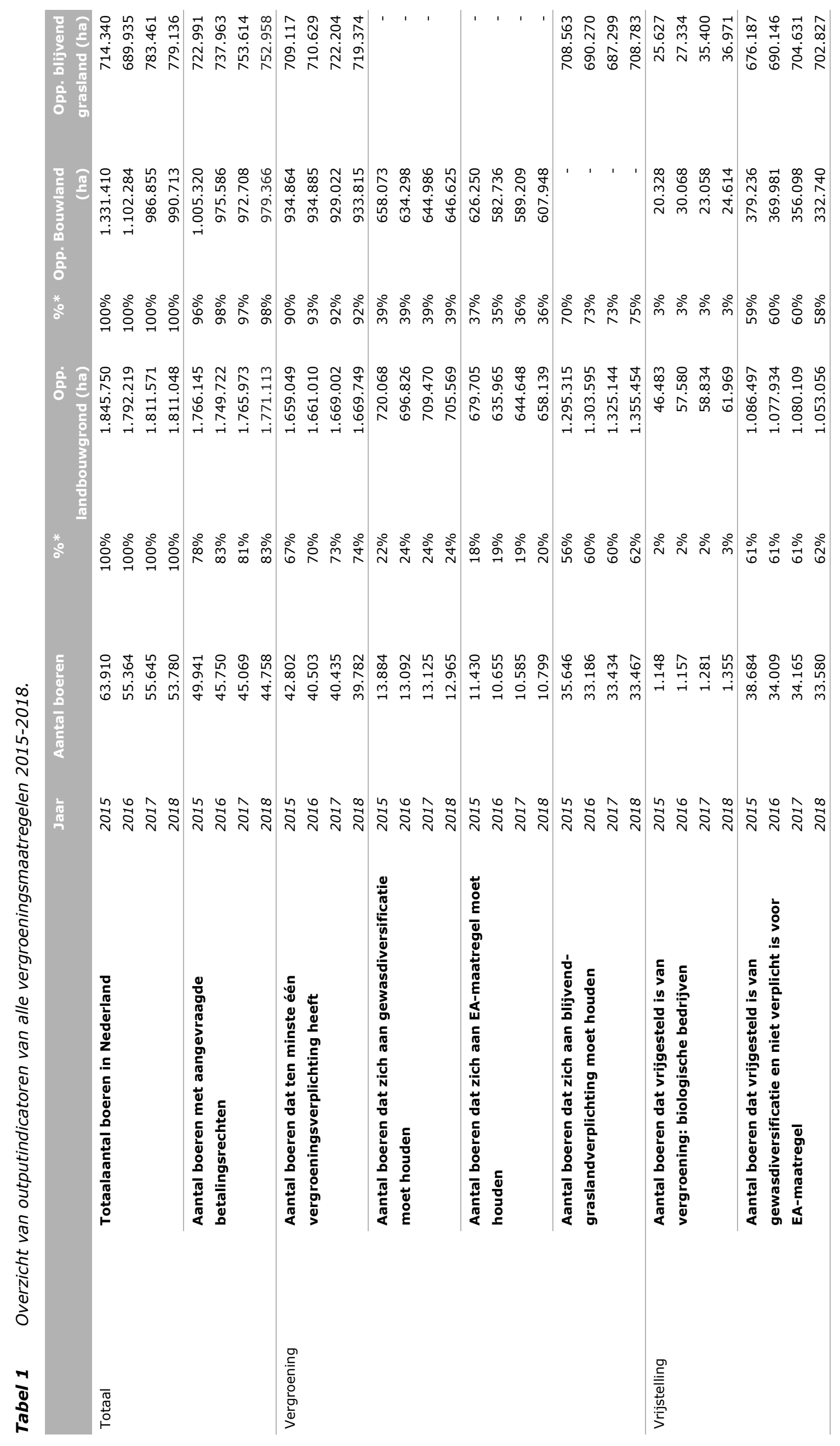




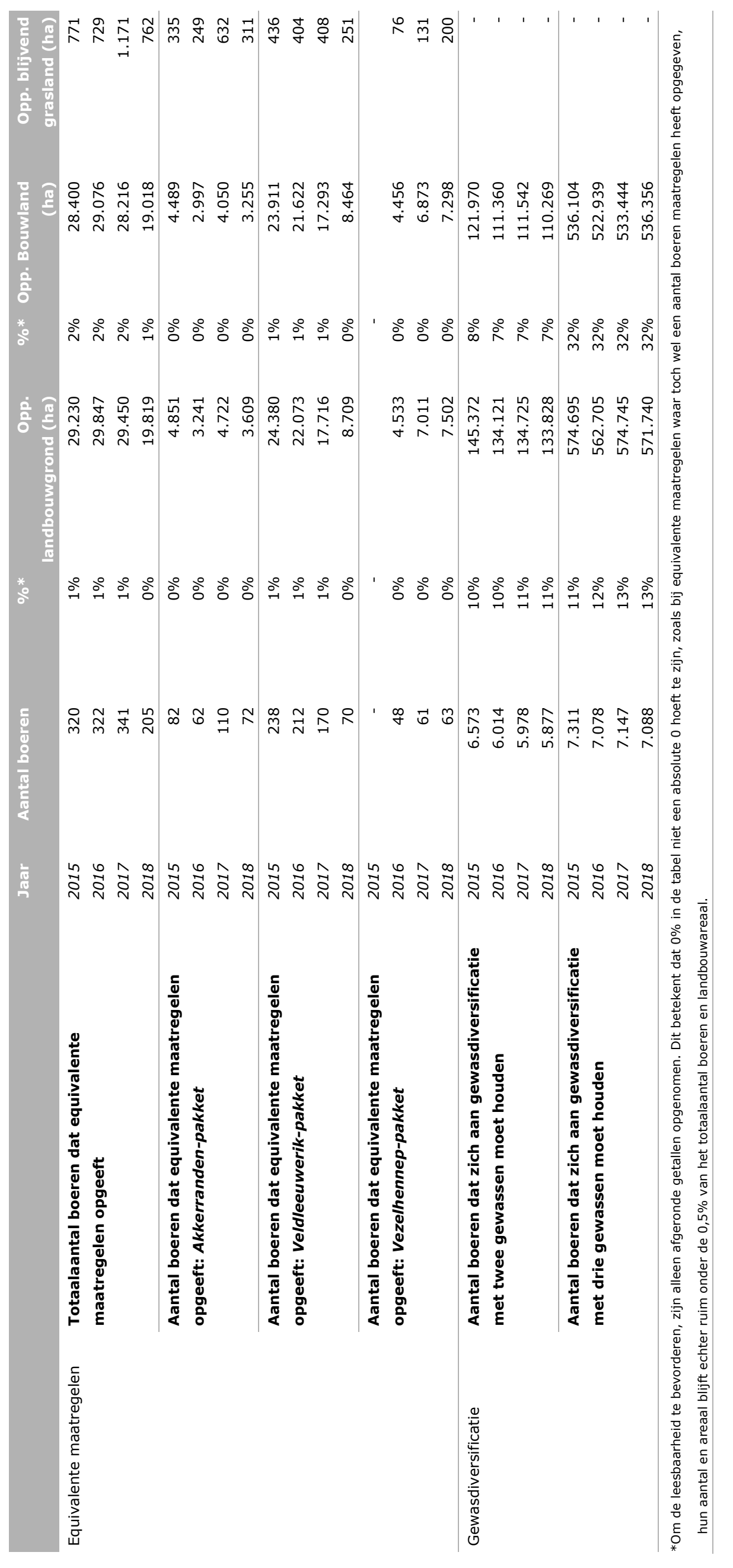


Het percentage boeren dat zich aan gewasdiversificatie moet houden, is ook tussen 2015 en 2018 gestegen van 22 naar 24\%, maar deze toename geldt niet voor het bijbehorende landbouw- en bouwlandareaal. Beide arealen nemen in dezelfde periode af (zie Tabel 1). Van het aantal boeren dat zich aan gewasdiversificatie met twee gewassen moet houden, neemt het aantal sterker af dan de boeren met gewasdiversificatieverplichting met drie gewassen. Dit betekent dat voornamelijk de groep grotere bedrijven, van meer dan 30 ha bouwland, de relatieve toename in gewasdiversificatieplichtige bedrijven van 22 naar $24 \%$ verklaart (zie Tabel 1 ).

De gewasdiversificatieverplichting zal overigens in de praktijk weinig inspanning vergen van boeren, aangezien de maatregel vrijwel niets toevoegt aan de gangbare landbouwpraktijk (Van Doorn \& Smidt, 2017; Europese Rekenkamer 2017; Louhichi et al., 2017).

Wat betreft equivalente maatregelen kunnen drie soorten pakketten worden opgegeven. In 2015 waren dit er nog twee, maar daar is het Vezelhenneppakket nog bijgekomen in 2016. In totaal namen er in 2017341 boeren deel aan equivalente maatregelen. In 2018 is dit aantal gedaald naar 205 boeren. Deze daling zit voornamelijk in de afname van het aantal boeren dat kiest voor het Veldleeuwerikpakket. Hun aantal is in de periode 2015-2018 met 70\% afgenomen. Deze afname hangt samen met een wijziging van de voorwaarden in de standaardsituatie (voorwaarden buiten de equivalente praktijken) waardoor het verschil met het equivalente pakket 'Veldleeuwerik' kleiner werd. Specifiek schreef het Veldleeuwerikpakket opname van vanggewassen (volgteelt) in het bouwplan voor, waarbij een keuze kon worden gemaakt tussen 8 weken vanggewas in stand houden, maar dan wel $20 \%$ meer oppervlakte vanggewas (dan de standaardsituatie), of 10 weken vanggewas in stand houden. Echter, de instandhoudingstermijn van de standaard vergroeningsmaatregel EA-vanggewassen is door de EU in 2018 verkort van 10 naar 8 weken. Omdat hiermee de geboden keuze binnen het Veldleeuwerikpakket feitelijk een lege huls werd, is bij het equivalente pakket 'Veldleeuwerik' de instandhoudingstermijn vervolgens ook op 8 weken gesteld. Hierdoor bestaat er geen verschil meer met de standaardsituatie EA-vanggewas. Dit is naar alle waarschijnlijkheid de reden dat minder landbouwers van het equivalente pakket 'Veldleeuwerik' gebruik gingen maken in 2018.

\subsection{Instandhouding blijvend grasland}

In Nederland wordt blijvend grasland op nationaal niveau gemonitord. Dit betekent dat het blijvend grasland (BG) areaal in Nederland ten opzichte van het referentiejaar 2012 met niet meer dan 5\% mag afnemen. Het gaat hierbij om het relatieve graslandareaal als percentage van het totale landbouwareaal. RVO monitort dit aandeel jaarlijks en heeft berekend dat het percentage voor het referentiejaar 2012 40,97\% bedraagt. Na een daling in de jaren 2015 tot en met 2017 ten opzichte van het referentiejaar laat 2018 nu een lichte stijging zien met 0,70\% (Tabel 2).

Tabel 2 Het aandeel blijvend grasland binnen het totaal landbouwareaal ten opzichte van het referentie jaar in 2012.

\begin{tabular}{lll} 
& \multicolumn{2}{c}{ Verandering t.0.v. referentieratio } \\
\hline Referentieratio & 40,97 & \\
\hline Aandeel 2015 & 40,59 & $-0,91 \%$ \\
\hline Aandeel 2016 & 40,56 & $-0,99 \%$ \\
\hline Aandeel 2017 & 40,15 & $-2,0 \%$ \\
\hline Aandeel 2018 & 41,26 & $+0,70 \%$ \\
\hline
\end{tabular}

Voor de vergroening zijn alle bedrijven met blijvend grasland automatisch vergroeningsplichtig, echter zolang de daling van het relatieve areaal niet meer dan $5 \%$ bedraagt, hoeft de ruime meerderheid van de boerenbedrijven met blijvend grasland ( $56 \%$ van alle landbouwbedrijven dat $83 \%$ van het totale blijvend grasland beheert) hier niets voor te doen. Ploegen en scheuren en omzetten op dit grasland mag gedaan worden. Het aandeel landbouw bedrijven met blijvend grasland is tussen 2015 en 2018 
relatief toegenomen, van 56 naar 62\%. Deze stijging ten opzichte van 2015 gaat gepaard met een kleine toename in het areaal blijvend grasland (zie Tabel 3). Deze lichte stijging is in 2018 in gang gezet, terwijl in de jaren ervoor juist sprake was van een daling (zie Tabel 3 en Kader 2).

Tabel 3 Overzicht van output indicatoren voor vergroening met blijvend grasland (BG) en Ecologisch Kwetsbaar Blijvend Grasland (EKBG) maatregelen.

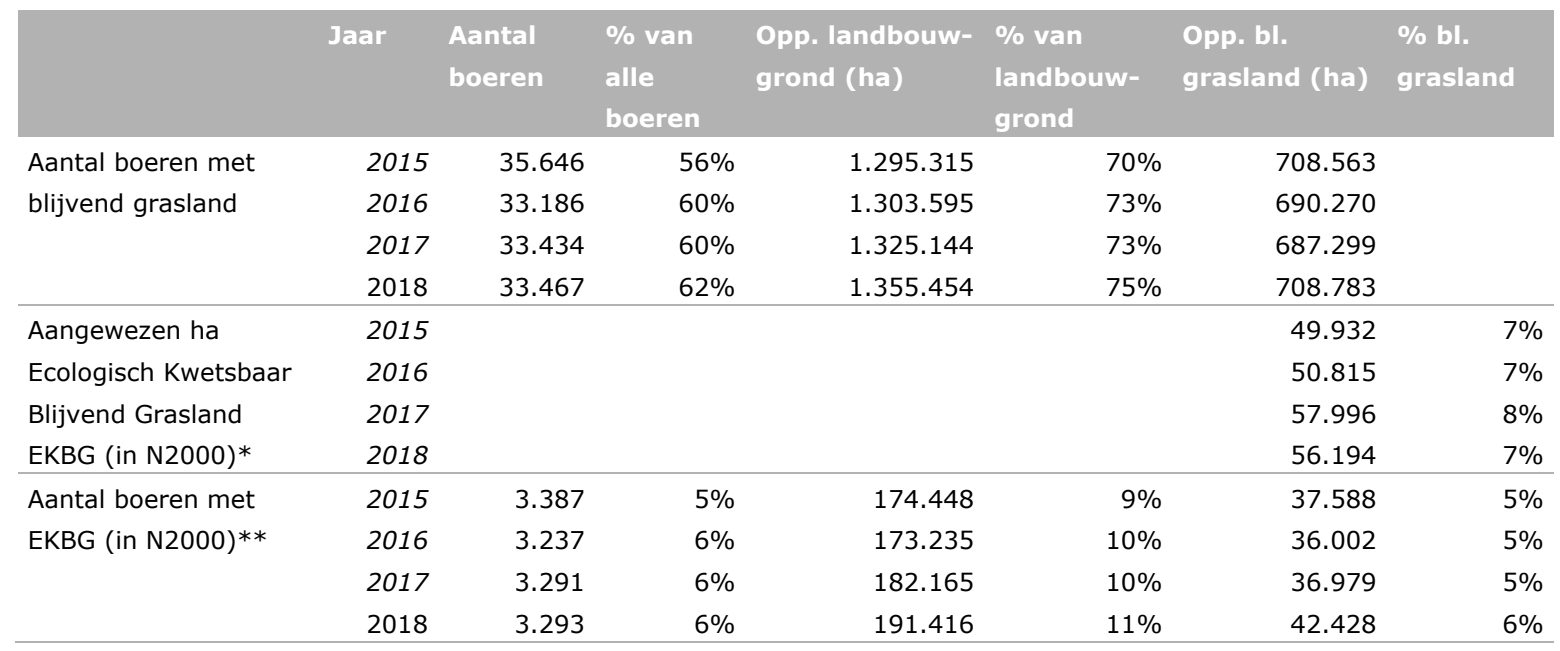

* Inclusief blijvend grasland bij niet-directe betaling aanvragers en blijvend grasland bij boeren vrijgesteld van betalingen en grasland met als hoofdfunctie natuur.

** Exclusief grasland van boeren die zijn vrijgesteld van vergroening en grasland met als hoofdfunctie natuur.

Voor 6\% van de boeren in 2018 (5\% in 2015) geldt een ploeg- en omzetverbod, omdat deze graslanden binnen Natura 2000-gebieden beheren en deze graslanden zijn aangewezen als Ecologisch Kwetsbaar blijvend grasland (EKBG). Nederland heeft ervoor gekozen $100 \%$ van al het blijvend grasland binnen Natura 2000-gebieden als kwetsbaar aan te wijzen. Dit komt overeen met een oppervlakte van 56.194 ha, wat overeenkomt met 7\% van het totale blijvend-graslandareaal in 2018 (zie Tabel 3). Echter, niet al deze hectaren kwetsbaar blijvend grasland vallen onder de vergroeningsverplichting. Zo behoort circa 5.100 ha van deze graslanden bij biologische bedrijven en die zijn per definitie groen en circa 8.650 ha heeft de functie natuur (i.p.v. landbouw), waardoor ook voor dit deel van het blijvend grasland geen vergroeningsverplichting geldt. Dit verklaart waarom slechts een deel van het totaal aangewezen areaal kwetsbaar blijvend grasland (EKBG) ook blijvend grasland is met een vergroeningsverplichting (Tabel 3).

Het omzetverbod voor blijvend grasland wordt daarmee op 42.428 ha door de maatregel vergroening gehandhaafd. In 2017 was er sprake van een lichte afname ten opzichte van 2015 van 2\%. In 2018 is er sprake van een toename van $13 \%$ ten opzichte van 2015 . De toename in areaal blijvend grasland kan worden verklaard door het in 2018 toestaan in de basisbetalingsregeling van zogenaamde IMNA-gronden. ${ }^{1}$ Hierdoor konden deze gronden worden opgegeven voor uitbetaling van betalingsrechten.

In Kader 2 wordt de trend in blijvend-graslandareaal in Nederland over de periode 2005-2018 toegelicht. Er is sprake van een daling, met name tussen 2011 en 2015 . Deze komt echter niet tot uiting in de trend waarop blijvend grasland gemonitord wordt voor het vergroeningsbeleid. Dit komt omdat het een relatieve trend betreft, die gebaseerd is op de verandering van het relatieve percentage blijvend grasland ten opzichte van het totale landbouwareaal conform Europese regelgeving. En aangezien ook het totale landbouwareaal sterker is gedaald in deze periode, is de relatieve daling van blijvend grasland zodoende ook veel minder.

\footnotetext{
${ }^{1}$ Het betreft percelen waarvoor in 2015, 2016 of 2017 geen betalingsrechten zijn toegekend, omdat deze als nietsubsidiabele natuurgronden werden beschouwd. Na uitspraak van het College van Beroep voor het bedrijfsleven (CBb) van 11 juli 2017, zijn deze percelen opnieuw beoordeeld. Een deel van deze percelen is alsnog als subsidiabele landbouwgrond in het perceelsregister opgenomen.
} 


\section{Kader 2: Ontwikkeling in blijvend grasland in Nederland 2005-2018}

Over een langere periode bekeken, fluctueert het areaal blijvend grasland en is er tussen 2005 en 2018 sprake van een absolute daling zoals uit de cijfers van RVO blijkt (zie Figuur 1). Tussen 2005 en 2018 is het totale blijvend-graslandareaal afgenomen van 792.014 tot 721.570 ha (zie Figuur 1 ). ${ }^{2}$ Tussen 2011 en 2015 is deze afnemende trend sterk, terwijl daarvoor ook sprake was van een lichte stijging. De trend waarop gemonitord wordt en die gebaseerd is op de verandering van het relatieve percentage blijvend grasland ten opzichte van het totale landbouwareaal, is veel kleiner. Dit komt omdat niet alleen het blijvend-graslandareaal daalt, maar ook het landbouwareaal (van 1,951,645 ha in 2005 naar $1,771,113$ ha in 2018).

\section{Ha blijvend grasland}

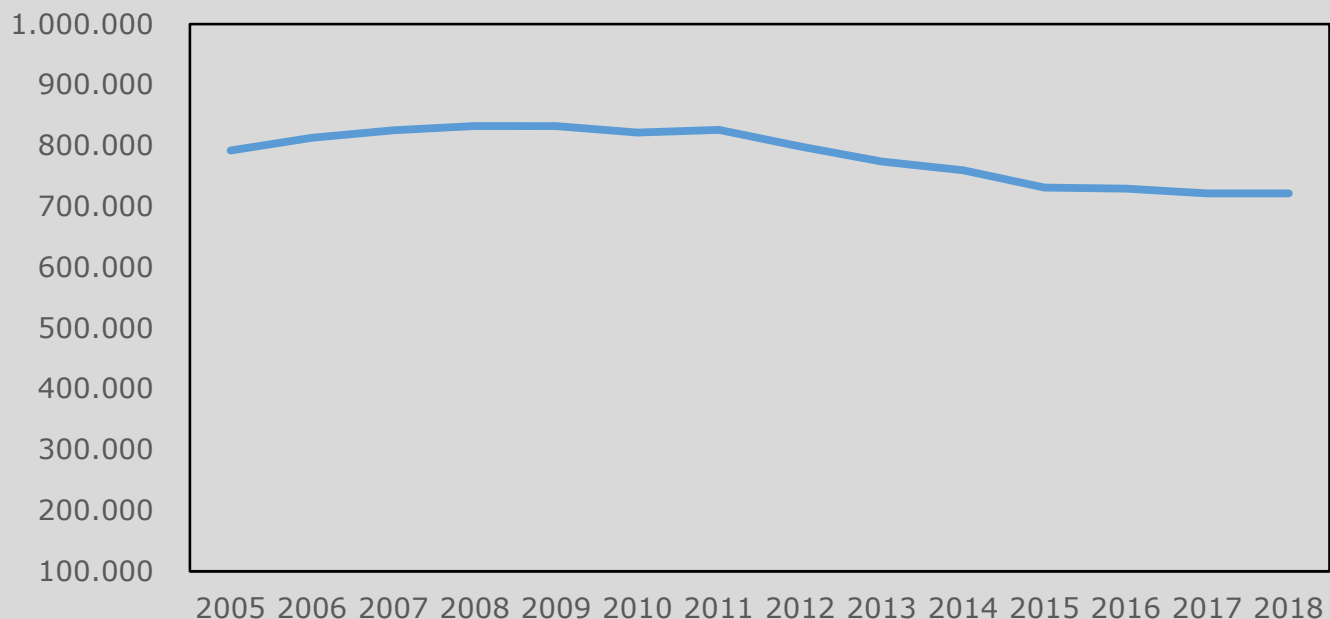

Figuur 1 Ontwikkeling in areaal (absoluut in hectaren) blijvend grasland 2000-2018 (Bron: Gerapporteerde cijfers van RVO, 1 juni 2019).

In Van Doorn en Smidt (2017) voor de monitoring van vergroening 2016 is ook gekeken naar waar de EKBG vooral liggen (zie Van Doorn en Smidt, 2017; pag. 11, Figuur 2). Deze analyse is voor dit rapport niet opnieuw gemaakt, aangezien hierin tussen 2016 en 2018 nauwelijks verandering verwacht kan worden. Voor 2016 is gebleken dat de aangewezen blijvende graslanden in kwetsbare gebieden vooral liggen in de uiterwaarden langs de grote rivieren, verspreide plekken in de veenweidegebieden van Noord-Holland, het Groene Hart en Arkenheem. Ook werd in Van Doorn en Smidt (2017) op de kaart de ligging van de aangewezen EKBG vergeleken met de ligging van overig waardevol grasland, zoals grasland dat belangrijk is voor weidevogels en gekenmerkt wordt door hoge natuurwaarden: de zogenaamde High Nature Value farmlands (uit Van Doorn et al., 2015). Gebleken is dat de grote meerderheid van deze overige waardevolle blijvende graslanden buiten Natura 2000areaal en dus buiten het aangewezen EKBG-areaal valt.

\subsection{Ecologische aandachtsgebieden (EA)}

Een overzicht van de outputindicatoren over de invulling van EA staan in Tabel 4. Uit de tabel blijkt dat het aantal boerenbedrijven met EA-verplichting is afgenomen van 11.430 in 2015 naar 10.799 in 2018. Deze boerenbedrijven beheren ongeveer $36 \%$ van het totale landbouwareaal in Nederland.

\footnotetext{
${ }^{2}$ Deze cijfers verschillen van die in Tabel 2 en 4, omdat dit totaal blijvend-graslandareaal betreft, inclusief graslanden met als hoofdfunctie natuur.
} 
Het aantal boeren dat voor een collectieve invulling van EA kiest, is praktisch nihil, met 12 boeren in 2015, 2 in 2016, 7 in 2017 en 5 boeren in 2018.

Op de bedrijven met EA-verplichting bedroeg de omvang EA, zonder weging, in 2015 26\% van het bouwlandareaal en dit is toegenomen naar $35 \%$ in 2018. Deze relatieve toename hangt samen met het feit dat er richting 2017 een verschuiving heeft plaatsgevonden, waarbij boeren nog iets meer EA's zijn gaan invullen met vanggewassen en stikstofbindende gewassen en nog minder met akkerranden.

Wel is het zo dat de vanggewassen een wegingsfactor van 0,3 hebben, dus elke hectare vanggewassen telt dus maar voor 0,3 ha mee als EA (zie Bijlage 2). Dit verklaart ook de absolute toename in het EA-areaal. Na toepassing van de wegingsfactoren bedraagt het percentage gewogen areaal EA van het totale bouwlandareaal tussen de 8-10 in de vier jaren. Dit is ruim boven de norm van $5 \%$ dat elk land verplicht is in te vullen met EA.

Uit de laatste kolom in Tabel 4 blijkt dat in Nederland EA-areaal voor 99\% wordt ingevuld door de productie-gerelateerde EA's en dat landschapselementen vrijwel niet gekozen worden, tenzij ze onder equivalente pakketten vallen. De belangrijkste soorten vanggewassen die gekozen worden, zijn bladrammenas, gele mosterd, Italiaans en Engels raaigras, Japanse haver en tijdelijk gras. Deze mix verandert weinig tussen de verschillende jaren.

De teelt van vanggewassen na het hoofdgewas heeft in potentie verschillende voordelen voor de bodem: het zorgt voor een toename in het organischestofgehalte in de bodem, er spoelen minder nutriënten uit en deze komen ook geleidelijker beschikbaar erna, er hoeft vervolgens minder (kunst)mest gebruikt te worden, de bodemstructuur verbetert, het heeft een positieve invloed op het bodemleven en het gaat erosie tegen. Echter, omdat het vanggewas slechts kort op het land staat, is de werkelijke bijdrage toch nog vrij onbekend en moet deze verder worden onderzocht. Bovendien dragen vanggewassen - en ook stikstofbindende gewassen - niet of nauwelijks bij aan het verbeteren van de leefruimte van flora en fauna. De ecologische meerwaarde van deze gewassen is dan ook zeer gering, zeker in vergelijking met de niet-productie gebonden EA's als akkerranden, landschapselementen en groene braak. Er kan dan ook geconcludeerd worden dat de inrichting van EA-gebied in Nederland niet bijdraagt aan de doelstelling die verbonden is aan deze maatregelen, namelijk meer ruimte te bieden voor biodiversiteit in bouwlandgebieden. Wel kan men constateren dat, sinds landschapselementen onderdeel zijn geworden van het EA-pakket in 2016, er een stijging is in het aantal boeren dat voor landschapselementen kiest (zie Tabel 4). Landschapselementen als percentage van EA-areaal blijft echter nog steeds erg laag ondanks deze toename.

In Van Doorn en Smidt (2017; Figuur 4, p. 13) is een kaart gepresenteerd van de ruimtelijke concentratie van EA's in Nederland; tussen 2015 en 2018 is deze verdeling niet veranderd. Nog steeds liggen de grootste oppervlakten EA's in de akkerbouwregio's, zoals de Veenkoloniën, het Noordelijk Zeekleigebied, Flevoland en de Noordoostpolder, de kop van Noord-Holland en Zeeland. 


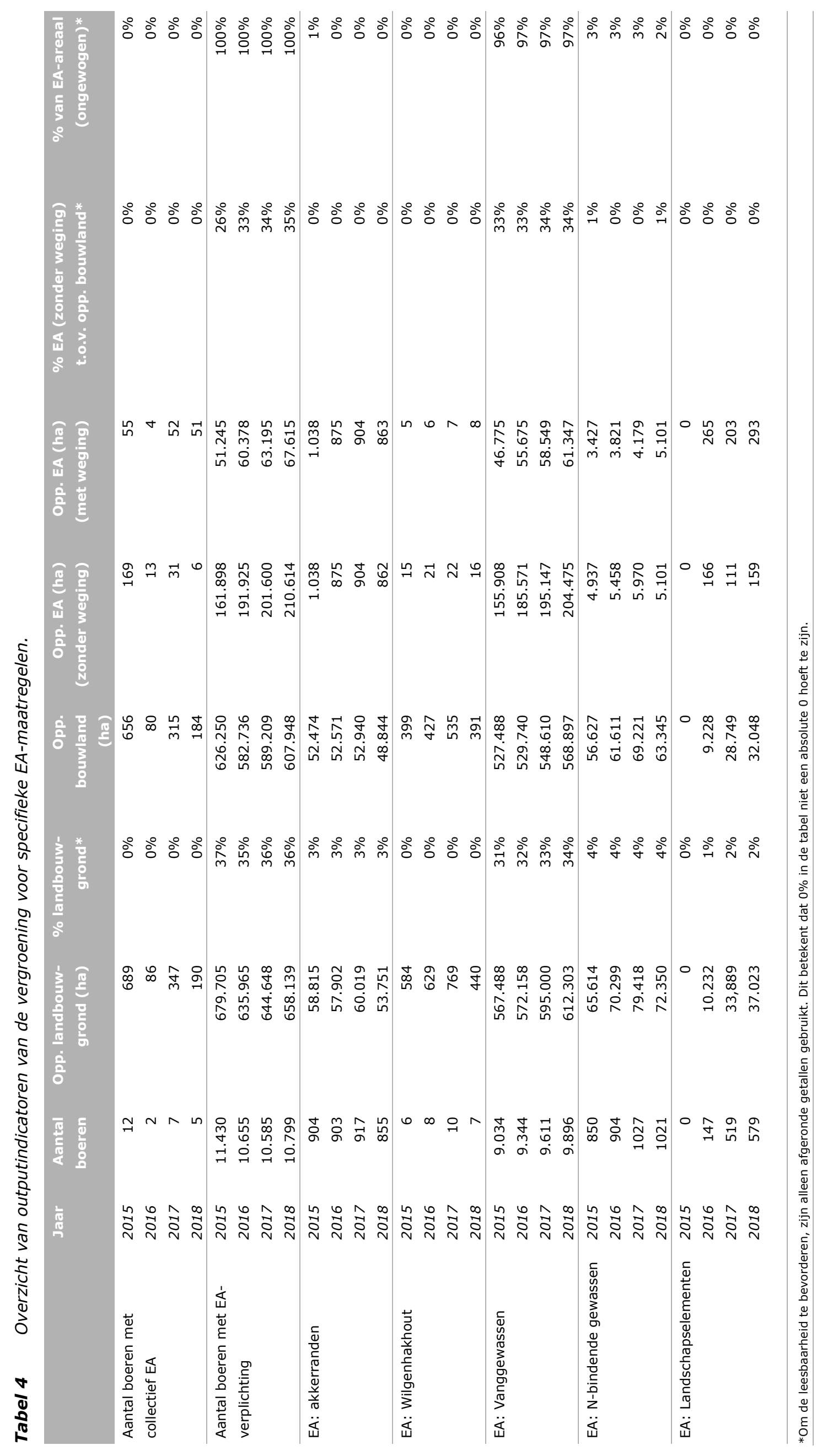




\section{Conclusies resultaten van vergroening na vier jaar}

De vergroeningsmaatregelen hebben in Nederland een grote reikwijdte, in die zin dat een groot gedeelte van het landbouwareaal in beheer is bij boeren met minimaal één vergroeningsverplichting. Dit areaal is tussen 2015 en 2018 ook toegenomen. In 2015 had 67\% van de boeren ten minste één vergroeningsverplichting en in 2018 was dit gestegen naar $74 \%$, wat vooral wordt verklaard door een stijging in het aantal boeren met een instandhoudingsverplichting blijvend grasland. De landbouwgrond die hoort bij deze bedrijven (met minimaal een vergroeningsverplichting) bedroeg $90 \%$ in 2015 en $92 \%$ in 2018. Gesteld kan worden dat Nederland hiermee hoog scoort in Europees perspectief, waar het gemiddelde percentage landbouwgrond dat ten minste onder één verplichting valt, op 73\% ligt (Europese Rekenkamer 2017). Dit hoge percentage landbouwgrond met ten minste één vergroeningsverplichting betekent niet dat er veel is veranderd in de landbouwpraktijk op bedrijven.

Ten eerste omdat dit percentage inclusief alle bedrijven met instandhoudingsverplichting voor blijvend grasland is. Deze bedrijven maken $62 \%$ van de bedrijven in Nederland uit. Ten tweede voegt de maatregel gewasdiversificatie weinig toe aan de gangbare landbouwpraktijk. Tussen 2015 en 2018 steeg het aandeel boeren dat zich hieraan moet houden wel van 22 naar $24 \%$, maar in de praktijk is de diversiteit in hoofdgewassen in de vergroeningsperiode 2015-2017 sterk afgenomen, zoals bleek uit cijfers gepresenteerd in Elbersen (et al., 2018). Ten derde geldt ook voor de maatregel EA dat deze maar op een klein aandeel van het landbouwareaal tot een verandering in de landbouwpraktijk leidt. In 2018 is $20 \%$ van de boeren verplicht aan deze maatregel te voldoen en het EA-areaal dat hierbij hoort, beslaat 210.614 ha (ongewogen), wat neerkomt op $12 \%$ van het landbouwareaal met betalingsrechten. Overigens valt Nederland hiermee boven het Europese gemiddelde wat betreft relatief areaal EA, dat boven de 5\% moet liggen.

De bedrijven (62\%) in Nederland met een instandhoudingsverplichting voor blijvend grasland moeten hun areaal blijvend grasland rapporteren in hun jaarlijkse perceelsopgave. $56 \%$ van de bedrijven in Nederland die onder de instandhoudingsverplichting voor blijvend grasland valt, hoeft - om de vergroeningspremie te ontvangen - geen aanvullende maatregelen te treffen. De andere $6 \%$ van de bedrijven heeft grasland in Natura 2000-gebieden dat is aangewezen als Ecologisch Kwetsbaar Blijvend Grasland (EKGB) en daarvoor geldt een omzet- en ploegverbod. Voor 56\% van de bedrijven gelden geen aanvullende maatregelen zolang de daling van het relatieve areaal blijvend grasland in het totale landbouwareaal niet meer dan $5 \%$ bedraagt ten opzichte van de permanent-graslandratio in het referentiejaar 2012. In 2018 was er sprake van een stijging van 0,7\% ten opzichte van het referentieratio.

Het totaalaantal hectaren blijvend grasland met een omzet- en ploegverbod gehandhaafd onder de vergroening, het zogenaamde EKBG en dus gelegen in Natura 2000-gebied, bedraagt 42.428 ha en dit betreft $6 \%$ van het totaalareaal blijvend grasland in Nederland. Nederland heeft ervoor gekozen om $100 \%$ van het blijvend-graslandareaal binnen Natura 2000 aan te wijzen als kwetsbaar. Dit komt overeen met een areaal van 56.194 ha (7\% van het totale permanent-graslandareaal). Slechts een deel van dit gebied valt echter onder het beheer van vergroeningsplichtige boeren en verklaart het grote verschil tussen aangewezen hectare ecologisch kwetsbaar blijvend grasland (EKBG) en opgegeven hectare onder vergroening.

Met het areaal EA kan in potentie een goede bijdrage geleverd worden aan natuur en biodiversiteit door het seminatuurlijke areaal op agrarisch land te vergroten. Dit was ook de oorspronkelijke bedoeling van de maatregel. Het merendeel van de boeren in Nederland heeft ervoor gekozen om EA's in te vullen met productie-gerelateerde EA's als vanggewassen en stikstofbindende gewassen, die hierdoor 99\% van het EA-areaal beslaan over de onderzochte periode van 2015 tot met 2018. Deze gewassen kunnen een positieve bijdrage leveren aan de bodem, hoewel nog onderzocht moet worden of deze bijdrage optimaal is, gegeven de korte tijd dat ze op het land staan; ze dragen echter vrijwel niets bij aan het verbeteren van natuur en biodiversiteit. Overigens heeft Nederland hiermee wel een 
uitzonderingspositie in de EU, waar gemiddeld $58 \%$ van het areaal wordt ingevuld met productiegerelateerde EA's en samen met Roemenië is Nederland het enige land dat op 99\% invulling van EA met vanggewassen en stikstofbindende gewassen uitkomt (EC, ECA-data 2016).

Voor zowel het vastleggen van bodemkoolstof als het beschermen van onder- en bovengrondse biodiversiteit, is het in stand houden van blijvend grasland belangrijk. Nederland heeft ervoor gekozen om $100 \%$ van het blijvend grasland in Natura 2000-gebied aan te wijzen als EKBG. Hierdoor geldt alleen binnen Natura 2000-gebieden een ploeg- en omzetverbod voor blijvend gras. Bescherming van blijvend grasland op basis van EU-regelgeving is ook toegestaan in andere gebieden, zoals weidevogelgebieden en veenweidegebieden, die in Nederland grotendeels buiten Natura 2000-gebied liggen.

Bij aanwijzing van kwetsbare graslanden scoort Nederland onder het EU-gemiddelde, waar gemiddeld $16 \%$ van de blijvende graslanden als kwetsbaar is aangewezen. In Nederland is $100 \%$ van het blijvend grasland in Natura 2000-gebied aangewezen als kwetsbaar, hetgeen betekent dat voor $7 \%$ van het blijvend grasland in 2018 een ploeg- en omzetverbod geldt.

Tot slot kan men concluderen dat uit de resultaten blijkt dat de vergroeningsmaatregelen weinig effectief zijn in de bijdrage aan het behalen van natuur- \& biodiversiteitsdoelen. Dit komt doordat de maatregelen op een beperkt areaal van toepassing zijn, de maatregelen zelf van weinig toegevoegde waarde zijn ten opzichte van de gangbare landbouwpraktijk en omdat het mogelijk is voor laagdrempelige, maar weinig effectieve EA-opties te kiezen. Dit sluit aan bij de conclusies die de Europese Rekenkamer (2017) ook na evaluatie van vergroening op EU-niveau heeft getrokken. 


\section{Literatuur}

Doorn, A Van, Vullings, W. \& Smidt, R., 2015. Nationale monitoring en evaluatie van de vergroening van het GLB. Systematiek en nulmeting. Wageningen Alterra Wageningen UR, Alterra rapport 2606.

Doorn, A. Van \& Smidt, R., 2017. Feiten en cijfers vergroening GLB. Wageningen Environmental Research. Rapport 2795.

Elbersen, B.S, Smidt, R. \& Doorn, van A., 2018. Feiten en cijfers vergroening GLB 2017. Wageningen, Wageningen Environmental Research, Rapport 2907. 36 blz.; 2 fig.; 10 tab.; 7 ref.

EC, 2016. Commission staff working document. Review of Greening after one year. SWD (2016) 218 final. Parts 1-6. Brussels 22nd of June 2016.

Ecorys, IEEP, WUR, 2016 Mapping and analysis of the implementation of the CAP https://ec.europa.eu/agriculture/sites/agriculture/files/external-studies/2016/mapping-analysisimplementation-cap/fullrep_en.pdf)

Europese Rekenkamer/European Court of Auditors, 2017. Greening: a more complex income support scheme, not yet environmentally effective. Report no. 21

Hart, K., 2015. 'Green direct payments: implementation choices of nine Member States and their environmental implications'

Louhichi, K., Ciaian, P., Espinosa, M, Perni, A., Gomez y Paloma, S., (2017). Economic impacts of CAP Greening; An application of an EU-wide individual farm model for CAP analysis (IFM-CAP), European Review of agricultural Economics, forthcoming.

Websites:

Basisbetaling en Nationale Reserve: https://www.rvo.nl/onderwerpen/agrarischondernemen/gemeenschappelijk-landbouwbeleid/gemeenschappelijk-landbouwbeleid/directe-glbsteun/basisbetaling-en-nationale 


\section{Bijlage 1 Invulling van vergroeningsmaatregelen in Nederland}

\section{Gewasdiversificatie}

Bij de invulling van de gewasdiversificatiemaatregel heeft de EU geen vrijheid gegeven aan de lidstaten voor nationale invulling. In alle lidstaten gelden daarom dezelfde verplichtingen en die schrijven voor dat bedrijven met tussen de 10 en 30 ha bouwland minimaal twee gewassen en bedrijven met meer dan 30 ha bouwland minimaal drie gewassen moeten telen. Bedrijven kunnen vrijstelling van gewasdiversificatie krijgen in de volgende gevallen:

1. Biologische bedrijven worden vrijgesteld voor de percelen waarop biologische productie plaatsheeft.

2. Als vorig jaar op een bedrijf meer dan $50 \%$ van het bouwland ongebruikt is gelaten en op de andere $50 \%$ bouwland een ander gewas is verbouwd dan er vorig jaar op dat perceel stond.

3. Als de oppervlakte bouwland op een bedrijf, inclusief tijdelijk grasland, niet meer dan 10 ha bedraagt.

4. Als de oppervlakte landbouwgrond op een bedrijf voor meer dan $75 \%$ wordt gebruikt voor de productie van grassen of andere kruidachtige voedergewassen, braak ligt of voor een combinatie daarvan wordt gebruikt, mits het akkerbouwareaal dat daar niet onder valt, niet meer dan 30 ha groot is. ${ }^{3}$

Voor bedrijven met gewasdiversificatieverplichting geldt tevens dat het grootste gewas niet meer dan $75 \%$ van het bouwland mag beslaan. Bij een verplichting voor gewasdiversificatie met drie gewassen geldt tevens dat de twee grootste gewassen samen niet meer dan $95 \%$ van de oppervlakte bouwland mogen beslaan.

\section{Ecologische aandachtsgebieden}

Nederland heeft gekozen voor de invulling met vijf ecologische aandachtsgebieden (EA's) uit de algemene lijst. Hiermee heeft Nederland gekozen voor een selectieve invulling van EA's. De vijf gekozen EA's zijn vang- en stikstofbindende gewassen, wilgenhakhout, akkerrand en met ingang van 2016 ook landschapselementen. ${ }^{4}$

Bij de invoering van vergroening is er de meeste discussie geweest over de invoering van de EA's zoals al omschreven in Van Doorn (et al., 2015). Enerzijds wordt van EA's de grootste ecologische meerwaarde verwacht als deze worden ingevuld met niet-productief gebruikte elementen als (liefst meerjarige) akkerranden, bufferstroken en braakland. Echter, bij de invoering was ook veel weerstand bij de landbouwsector, die negatieve economische effecten verwachtte van het uit productie nemen van $5 \%$ van het landbouwareaal. Bij invoering van de EA's zijn daardoor - naast de akkerranden en landschapselementen - ook vanggewassen en stikstofbindende gewassen opgenomen in de Europese longlist en Nederland heeft deze beide typen gewassen ook opgenomen in de nationale lijst.

Tegelijkertijd heeft Nederland er ook voor gekozen om braak niet op te nemen in de nationale lijst, terwijl die wel op de Europese longlist voorkomt en ook door de meeste andere Europese lidstaten gekozen is. Vanwege de grote verscheidenheid in EA's en het verschil in potentiële ecologische meerwaarde en economische kosten is er ook een systematiek aan omzettings- en wegingsfactoren aan typen EA's verbonden. Een overzicht van deze wegingsfactoren voor de EA's die Nederland heeft gekozen, is te vinden in Bijlage 2.

\footnotetext{
${ }^{3}$ Op 1 januari 2018 zijn er technische aanpassingen van het gemeenschappelijk landbouwbeleid (GLB) in werking getreden via de omnibusverordening (2017/2393). Hierdoor geldt vanaf 20181 ) de vrijstelling voor gewasdiversificatie ook voor bedrijven met meer dan $75 \%$ vlinderbloemige gewassen en 2 ) is de 30 ha-grens voor het overige akkerbouwareaal komen te vervallen.

${ }^{4}$ Overigens worden vanaf 20193 nieuwe EA's toegevoegd in Nederland; deze betreffen gebieden met Miscanthus, gebieden in groene braak met Silphium perfoliatum of met melliferous (honingrijke) planten.
} 
Landschapselementen hebben een weegfactor variërend van 1,5 tot 2 vanwege de grotere potentiële bijdrage aan biodiversiteit. Dit betekent dat bijvoorbeeld houtwallen met een oppervlakte van 1 ha, die een wegingsfactor van 2 hebben, voor 2 ha meetellen als ecologisch aandachtsgebied. Bij invulling met niet-productieve EA's, zoals landschapselementen of beheerde akkerranden, hoeft men dus minder dan $5 \%$ van het bouwland als EA in te richten. Landschapselementen als heggen, houtwallen en bomen in rij hebben met 2 de hoogste wegingsfactor van alle EA's.

De gewassen die in Nederland als vanggewas en stikstofbindende kunnen worden ingezet, zijn genoemd in Bijlage 2. De gewassen die in Nederland als stikstofbindende gewassen kunnen worden opgegeven, zijn ingedeeld in drie categorieën, waarbij bepaalde gewassen in meerdere categorieën voorkomen. Categorie 1 betreft de algemene categorie vanggewassen, categorie 2 betreft vanggewassen die helpen bij de bestrijding van aaltjes - en mogen bij uitzondering in combinatie met gewasbeschermingsmiddelen gebruikt worden ${ }^{5}$ - en categorie 3 betreft alle tijdelijke en blijvende grassoorten die in Nederland gebruikt worden en met ingang van 2018 kan categorie 3 ook bestaan uit gras e/o vlinderbloemigen.

In Tabel 1 is aangegeven welke bedrijven vrijgesteld zijn van EA's. Alle bedrijven met meer dan 30 ha bouwgrond zijn in ieder geval EA-plichtig. Bedrijven die tot 15 ha bouwland hebben of biologisch (een SKAL-nummer hebben) zijn vrijgesteld van EA (zie ook Tabel 1).

Tabel 1 Overzicht van kenmerken waarbij EA verplicht en niet verplicht is.

\begin{tabular}{|c|c|}
\hline Kenmerk & Vrijgesteld van EA \\
\hline Biologisch bedrijf & $\begin{array}{l}\text { Vrijgesteld, tenminste voor het deel van het landbouwbedrijf } \\
\text { dat biologisch is. Voor het andere deel wel EA-plicht (zoals } \\
\text { hieronder). }\end{array}$ \\
\hline Oppervlakte bouwland maximaal 15 ha & Vrijgesteld \\
\hline $\begin{array}{l}\text { Oppervlakte bouwland tussen }>15-30 \text { ha en }>75 \% \\
\text { uit tijdelijk grasland, braak en vlinderbloemigen }\end{array}$ & Vrijgesteld \\
\hline $\begin{array}{l}>15-30 \text { ha en }>75 \% \text { uit tijdelijk grasland en } \\
\text { blijvend grasland }\end{array}$ & Vrijgesteld \\
\hline Oppervlakte bouwland > 30 ha & EA-plichtig \\
\hline
\end{tabular}

Nederland heeft bij de invulling van EA ook gekozen voor de collectieve invulling. Dit geldt voor landbouwers die met minimaal twee en maximaal tien landbouwers een collectief vormen (met collectieve overeenkomst gemeld bij RVO). Alle bedrijven die in dit collectief participeren, moeten bijeen liggen, d.w.z. dat $80 \%$ van de collectieve grond binnen een cirkel van $15 \mathrm{~km}$ bijeen ligt. De collectief ingebrachte EA's moeten aangrenzend zijn (mogen niet gescheiden door sloot of weg). Bovendien mag een deelnemer maximaal 50\% van de eigen EA-verplichting laten invullen door een ander bedrijf in het collectief en is dus verplicht altijd $50 \%$ van de EA in te vullen op het eigen bedrijf. Uit het overzicht van resultaatindicatoren in hoofdstuk 2 zal echter blijken dat hier praktisch geen gebruik van wordt gemaakt.

Tot slot moet nog vermeld worden dat bepaalde EA's kunnen samenvallen met elementen die beheerd kunnen worden via agrarisch natuurbeheer (SAN/SN). Zet een agrariër dit agrarisch natuurbeheer geheel of gedeeltelijk in om aan de verplichting van EA te voldoen, dan is dit toegestaan. Echter zal er dan wel een korting komen op de betaling voor agrarisch natuurbeheer, anders is er sprake van dubbele betaling. Dit geldt voor EA's als vang- en stikstofbindende gewassen, akkerranden en wilgenhakhout, maar niet voor landschapselementen. De subsidie voor beheer van landschapselementen wordt niet verlaagd bij overlap met EA, omdat beheer van deze elementen bij vergroening niet verplicht is, terwijl dit juist wel het doel is van de agrarisch-natuurbeheerregeling.

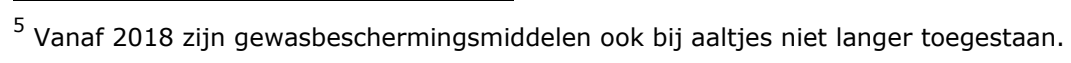




\section{In stand houden van blijvend grasland}

In de vergroening zijn eigenlijk twee maatregelen van toepassing, met als doel het in stand houden van blijven grasland. Enerzijds moet blijvend grasland gemonitord worden op nationaal niveau, zodat op tijd ingegrepen kan worden bij een daling van het areaal blijvend grasland met meer dan $5 \%$. Anderzijds geldt er een ploeg- en omzetverbod voor blijvend grasland gelegen in Natura 2000gebieden.

Bij de instandhouding van blijvend grasland heeft Nederland gekozen voor monitoring op nationaal en niet op regionaal niveau. Dat betekent dat als het graslandareaal met meer dan $5 \%$ op nationaal niveau terugloopt ten opzichte van de referentieratio, Nederland ervoor moet zorgen dat het aandeel weer voldoende stijgt door het invoeren van een herinzaaiplicht. Dat laatste houdt in dat boeren verplicht worden een perceel met gras in te zaaien en dit grasland moet ook blijven. In Nederland ligt de referentieratio (gebaseerd op 2012) voor blijvend grasland op 40,97\%. Door RVO is berekend dat er in 2018 sprake was van een relatieve toename in blijvend grasland van 0,7\%. Er is dus in 2018 geen reden om maatregelen te treffen.

Wat betreft de aanwijzing van kwetsbare blijvende graslanden heeft Nederland gekozen voor aanwijzing van $100 \%$ van het blijvend grasland binnen Natura 2000-gebieden voor een ploeg- en omzetverbod. Bij nationale vergroeningsinvulling heeft de EU landen ook de vrijheid gegeven om blijvende graslandgebieden buiten Natura 2000-gebieden aan te wijzen voor een ploeg- en omzetverbod. Dit kan gedaan worden met het doel van verbetering van de biodiversiteit, de bodemen waterkwaliteit, maar met name ter bescherming van klimaat via koolstofvastlegging. Nederland heeft er echter, net als de grote meerderheid van de EU-landen, voor gekozen om kwetsbare graslandgebieden met een ploeg- en omzetverbod te beperken tot Natura 2000-gebieden.

Omdat instandhouding van blijvend grasland een vergroeningsverplichting is, vallen alle landbouwbedrijven met blijvend grasland automatisch onder de vergroeningsverplichting. Echter voor boeren met blijvend grasland buiten Natura 2000-gebied leidt dit niet tot een bepaalde verplichting. Zij mogen grasland nog steeds omploegen en scheuren, zolang er geen sprake is van een nationale daling van meer dan $5 \%$, en dat is op dit moment bij lange na niet het geval. Voor boeren met blijvend grasland binnen Natura 2000-gebied geldt daarentegen wel een verplichting om zich aan het ploeg- en omzetverbod van blijvend grasland te houden. Overigens zijn er nog wel bepaalde vormen van lichte grondbewerking toegestaan in Natura 2000-gebieden, mits de ondergrond van het grasland vrijwel onberoerd blijft en er altijd een dekkende vegetatie zichtbaar blijft. De boeren met blijvend grasland in Natura 2000-gebieden zijn verplicht blijvend grasland ook als blijvend grasland te registreren in de perceelregistratie.

\section{Equivalente maatregelen}

In Nederland waren tot 2016 twee equivalente pakketten met een duurzaamheidscertificaat mogelijk: het Akkerbouwstrokenpakket en het pakket Veldleeuwerik. Vanaf 2016 kunnen boeren voor het pakket Vezelhennep ook een duurzaamheidscertificaat ontvangen en kan deze dus als equivalente maatregel dienen. In Tabel 1 wordt aangegeven wat deze maatregelen inhouden en in hoeverre ze verschillen van de standaard vergroeningsverplichtingen. 
Tabel 2 Equivalente pakketten in Nederland 2015-2017 (voorwaarden 2018 zijn gewijzigd).

Equivalent pakket Beschrijving pakket

Akkerbouw-strokenpakket

Dit is een pakket waarvoor akkerranden met beheereisen gelden. De stroken moeten tussen de 3 en $20 \mathrm{~m}$ breed zijn. Deze stroken (tot maximaal $20 \mathrm{~m}$ breed) mogen (geheel of gedeeltelijk) worden ingezet als EA.

$30 \%$ EA moet akkerrand zijn en $50 \%$ moet overwinteren.

Sloot naast beheerde rand mag meetellen.

Pakket Veldleeuwerik (VL) $\quad$ Dit is een certificaat voor grondgebonden open teelten met ISO-certificaat (ISO 17065)

VL-telers moeten zich wel aan gewasdiversificatie en EA-invulling houden, maar bij de invulling van EA gelden iets aangepaste regels:

- VL-telers kunnen een akkerrand inzaaien en hoeven zich niet te houden aan de minimale breedte van $3 \mathrm{~m}^{7}$, maar slechts gemiddeld $1 \mathrm{~m}$. De weegfactor van 1,5 is van toepassing en als de akkerrand ${ }^{8}$ aan de sloot grenst, kan ook de sloot worden meegenomen met weegfactor 2.

- VL-telers hebben niet de verplichting dat de beheerde akkerrand ten minste $30 \%$ van de totale EA-oppervlakte moet zijn en dat niet minimaal 50\% hoeft te overwinteren.

- Vanggewassen mogen 8 i.p.v. 10 weken staan, maar moeten gecompenseerd worden door aanleg van extra EA.

Pakket vezelhennep 9

Akkerbouwers met dit certificaat moeten hun EA-verplichting invullen met de teelt van hennep. Percelen met hennep hebben een wegingsfactor van 0,3 ( 1 ha hennep telt mee voor 0,3 ha vergroening). Telers die gebruikmaken van het duurzaamheids-certificaat Vezelhennep dienen hun EA-verplichting volledig in te vullen met de teelt van vezelhennep. Op die percelen mag tussen het moment van zaaien en het moment van oogsten geen gewasbeschermingsmiddel worden toegepast.

\footnotetext{
${ }^{6}$ In 2018 is er een voorwaarde voor de standaardsituatie (voorwaarden buiten de equivalente praktijken) gewijzigd, waardoor het verschil met het equivalente pakket 'Veldleeuwerik' kleiner is geworden. Het gaat over de instandhoudingstermijn van EA-vanggewassen - volgteelt: deze is in 2018 voor de standaardsituatie verkort van 10 naar 8 weken. Bij het equivalente pakket 'Veldleeuwerik' bleven de voorwaarden of 8 weken vanggewas in stand houden, maar dan wel $20 \%$ meer oppervlakte vanggewas, of 10 weken vanggewas in stand houden.

7 Is 5 meter geworden in 2018.

8 Met ingang van 2018 bij beheerde akkerrand Wegingsfactor 1,5 en bij onbeheerde akkerrand 1,0.

${ }^{9}$ Wijziging: met ingang van 2018 mag het areaal ook met vanggewassen worden ingevuld, mits meer dan $50 \%$ nog steeds uit vezelhennep bestaat
} 


\section{Bijlage 2 Overzicht voorwaarden en wegingsfactoren voor ecologische aandachtsgebieden 2018 (Algemene lijst)}

\begin{tabular}{|c|c|c|c|}
\hline Type EA & $\begin{array}{l}\text { Wegings- } \\
\text { factor }\end{array}$ & Voorwaarden & Toegestane soorten \\
\hline $\begin{array}{l}\text { Stikstofbindende } \\
\text { gewassen }\end{array}$ & 1 & $\begin{array}{l}\text { - Een van de toegestane soorten inzaaien. Dit } \\
\text { mag ook een mengsel zijn waarbij het totaal } \\
\text { aan stikstofbindende gewassen overheerst } \\
\text { (meer dan } 50 \% \text { ). } \\
\text { - Nateelt van een van de vanggewassen } \\
\text { algemeen (categorie } 1 \text { ) verplicht op zanden en } \\
\text { lössgronden als de teelt voor } 1 \text { oktober wordt } \\
\text { beëindigd. Deze nateelt is aanwezig van } 1 \\
\text { november tot } 1 \text { maart. } \\
\text { - Bij soja (Glycine) is het gebruik van } \\
\text { stikstofmeststoffen niet toegestaan. } \\
\text { - Gebruik van gewasbeschermings-middelen mag } \\
\text { niet. Ook niet op het zaaizaad (ontsmet, gecoat } \\
\text { of gepilleerd). } \\
\text { - Het stikstofbindende gewas moet in de periode } \\
\text { van } 15 \text { mei tot } 15 \text { juli geteeld worden. } \\
\text { - Bij gebruik van een zaaizaadmengsel bewaart u } \\
\text { de aankoopbewijzen en etiketten van het } \\
\text { gebruikte zaaizaadmengsel gedurende } 5 \text { jaar in } \\
\text { uw administratie en kunt u aantonen dat in het } \\
\text { mengsel één of meer toegestane } \\
\text { stikstofbindende gewassen overheersen. } \\
\text { - U geeft in de Gecombineerde opgave de } \\
\text { gewascode op van het stikstofbindende gewas } \\
\text { dat in het mengsel het grootste aandeel heeft. }\end{array}$ & $\begin{array}{l}\text { Veldbonen (o.a. duiven-, } \\
\text { paarden-, wierbonen), luzerne, } \\
\text { niet bittere lupinen, sojabonen, } \\
\text { afrikaantje, rode klaver, } \\
\text { rolklaver, esparcette, } \\
\text { voederwikke }\end{array}$ \\
\hline Wilgenhakhout & 0,5 & $\begin{array}{l}\text { - Maximale omlooptijd van } 5 \text { jaar. } \\
\text { - Gebruik meststoffen en } \\
\text { gewasbeschermingsmiddelen niet toegestaan. }\end{array}$ & Wilg \\
\hline $\begin{array}{l}\text { Vanggewassen } \\
\text { Cat. 1: algemeen } \\
\text { vanggewas } \\
\text { Cat. 2: } \\
\text { aaltjesbestrijding }\end{array}$ & 0,3 & $\begin{array}{l}\text { - Mengsel van minimaal } 2 \text { toegestane soorten } \\
\text { inzaaien. Kijk voor de toegestane soorten in de } \\
\text { tabel Gewassen en GLB } 2018 \text {. b. Inzaaien na } \\
\text { oogsten hoofdteelt en na } 15 \text { juli en uiterlijk } 15 \\
\text { oktober. Bij inzaai op of voor } 15 \text { juli start de } 8 \\
\text { wekentermijn altijd op } 15 \text { juli. } \\
\text { - Zaait u een vanggewas later dan u heeft } \\
\text { opgegeven in de Gecombineerde opgave? Dan } \\
\text { meldt u de werkelijke inzaaidatum uiterlijk op } \\
\text { de dag dat u aanvankelijk als inzaaimoment } \\
\text { had opgegeven. Zaait u een vanggewas eerder } \\
\text { dan u heeft opgegeven in de Gecombineerde } \\
\text { opgave? Dan meldt u de werkelijke inzaaidatum } \\
\text { uiterlijk op de dag van inzaai. Dit is de } \\
\text { ingangsdatum voor de } 8 \text { wekenperiode. d. } \\
\text { Minimaal } 8 \text { weken op het land. Tijdens de } 8 \\
\text { wekenperiode geen activiteiten verrichten die }\end{array}$ & $\begin{array}{l}\text { Cat. 1: Kapucijners, } \\
\text { groene/gele/groen en droog te } \\
\text { oogsten erwten, lupine, lijnzaad } \\
\text { van olievlas, vezelvlas, gele en } \\
\text { Ethiopische mosterd, } \\
\text { zwaardherik, (Japanse, rode, } \\
\text { Alexandrijnse, incarnaat \& } \\
\text { witte) Perzische) klaver, bonte } \\
\text { en voeder wikke, } \\
\text { beemdlangbloem, bladkool, } \\
\text { bladraap, bladrammenas, deder, } \\
\text { (Engels, Italiaans, Westerwolds) } \\
\text { raaigras, facelia, Franse } \\
\text { boekweit, Niger, rietzwenkgras, } \\
\text { sarepte mosterd, Soedangras, } \\
\text { spurrie, Seradelle } \\
\text { stoppelknollen, timothee, } \\
\text { veldbeemdgras. }\end{array}$ \\
\hline
\end{tabular}




\begin{tabular}{|c|c|c|c|}
\hline Tyре EA & $\begin{array}{l}\text { Wegings- } \\
\text { factor }\end{array}$ & Voorwaarden & Toegestane soorten \\
\hline & & $\begin{array}{l}\text { het gewas en de doelstelling ervan (stikstof } \\
\text { opvangen) kunnen beschadigen. O.a. begrazen, } \\
\text { maaien/klepelen is niet toegestaan. } \\
\text { - Meststoffengebruik mag. f. Gebruik } \\
\text { gewasbeschermingsmiddel mag niet vanaf } \\
\text { moment van oogst hoofdgewas en t/m de } 8 \\
\text { wekenperiode dat het vanggewas minimaal op } \\
\text { het land moet staan. g. Vanggewassen na maïs } \\
\text { op zand- en lössgronden tellen niet mee. } \\
\text { - U gebruikt ten minste } 75 \% \text { van de in de } \\
\text { Aanbevelende Rassenlijst voor } \\
\text { landbouwgewassen (CSAR) aanbevolen } \\
\text { hoeveelheid zaaizaad of u zorgt voor een } \\
\text { voldoende zichtbare bedekking van de bodem } \\
\text { met het vanggewas. Op de pagina Ecologisch } \\
\text { aandachtsgebied vindt u de Aanbevelende } \\
\text { rassenlijst. } \\
\text { - U bewaart aankoopbewijzen en etiketten van } \\
\text { het gebruikte zaaizaad(mengsel) } 5 \text { jaar lang in } \\
\text { voorjaar wordt geoogst. }\end{array}$ & $\begin{array}{l}\text { Cat. 2: Afrikaantje, raketblad, } \\
\text { zwaardherik, Japanse klaver } \\
\text { Cat. 3: tijdelijk gras, (Engels, } \\
\text { Italiaans, Westerwolds) } \\
\text { raaigras, Soedangras, spurrie en } \\
\text { veldbeemdgras }\end{array}$ \\
\hline $\begin{array}{l}\text { Vanggewas onderzaai } \\
\text { van gras en } \\
\text { vlinderbloemige } \\
\text { gewassen (Cat. } 3 \text { ) }\end{array}$ & 0,3 & 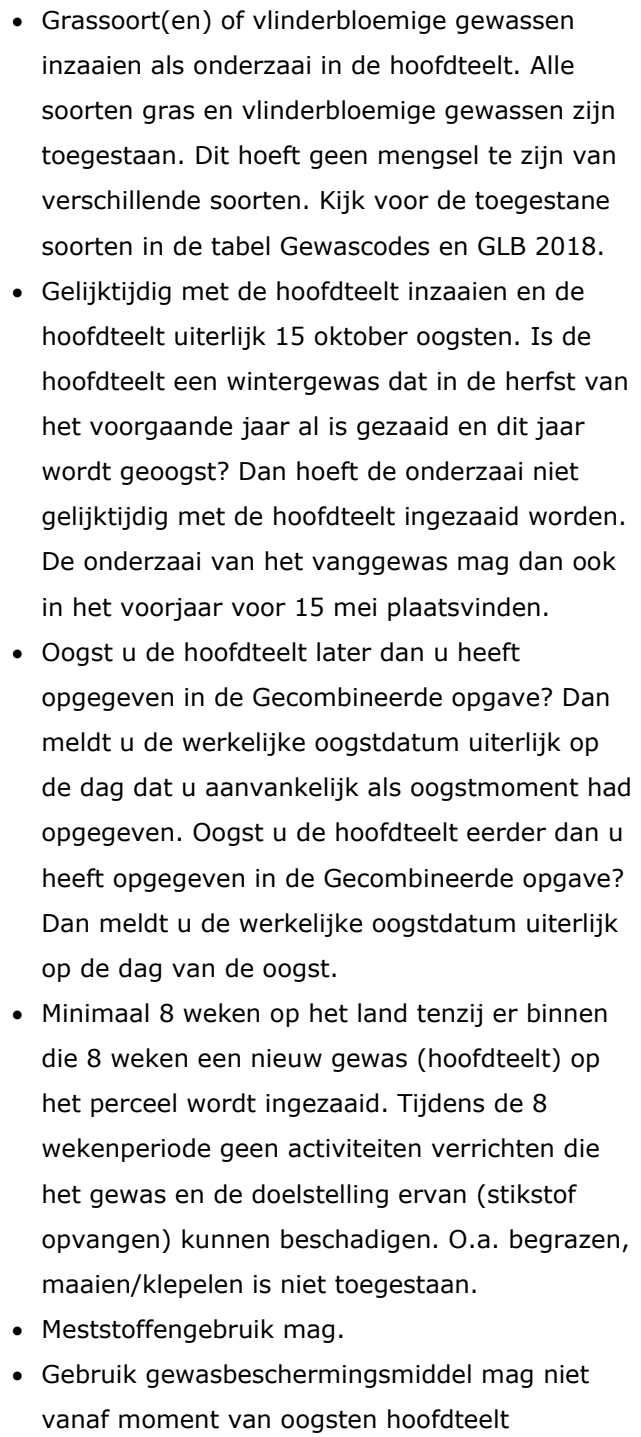 & \\
\hline
\end{tabular}




\begin{tabular}{|c|c|c|c|}
\hline Type EA & $\begin{array}{l}\text { Wegings- } \\
\text { factor }\end{array}$ & Voorwaarden & Toegestane soorten \\
\hline & & $\begin{array}{l}\text { (gedurende ten minste } 8 \text { weken) of tot de } \\
\text { inzaai van de volgende hoofdteelt. }\end{array}$ & \\
\hline $\begin{array}{l}\text { (Onbeheerde) } \\
\text { akkerrand } \\
\text { bufferstrook }\end{array}$ & 1 & 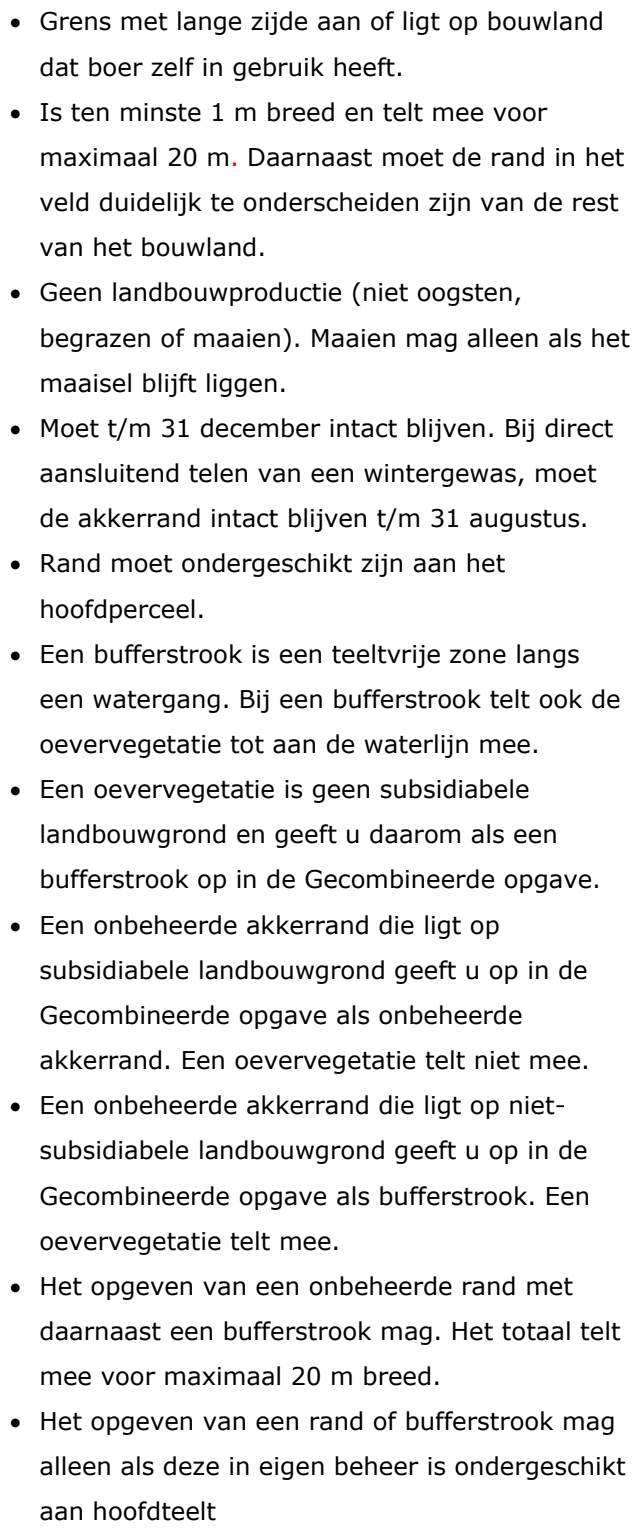 & $\begin{array}{l}\text { Ingetekende werkelijke } \\
\text { oppervlakte telt mee als EA }\end{array}$ \\
\hline $\begin{array}{l}\text { Stroken bouwland } \\
\text { langs bos }\end{array}$ & 1,0 & $\begin{array}{l}\text { - De strook ligt op subsidiabel bouwland dat u } \\
\text { zelf in gebruik heeft en grenst met de lange } \\
\text { zijde direct aan bos. Er mag geen sloot of iets } \\
\text { anders tussen strook en bos liggen. } \\
\text { - De strook is minimaal } 1 \mathrm{~m} \text { breed en mag } \\
\text { meetellen voor EA tot maximaal } 20 \text { m breed. } \\
\text { - De strook wordt niet gebruikt voor } \\
\text { landbouwproductie (niet oogsten, begrazen of } \\
\text { maaien). Maaien mag alleen als het maaisel } \\
\text { blijft liggen. } \\
\text { - De strook moet het hele jaar intact blijven. }\end{array}$ & $\begin{array}{l}\text { Ingetekende (werkelijke) } \\
\text { Oppervlakte telt mee tot } \\
\text { maximaal } 20 \mathrm{~m} \text { breed }\end{array}$ \\
\hline Vijvers/ poelen & 1,5 & $\begin{array}{l}\text { - De maximale oppervlakte voor een vijver die } \\
\text { mag meetellen voor EA is van 0,1 ha naar 0,3 } \\
\text { ha gegaan in } 2018 \text {. } \\
\text { - Geen reservoir van beton/plastic. } \\
\text { - Oever tot max. } 10 \text { m mag worden } \\
\text { meegerekend }\end{array}$ & $\begin{array}{l}\text { Ingetekende werkelijk } \\
\text { oppervlakte telt mee als EA }\end{array}$ \\
\hline Heggen/houtwallen & 2 & $\begin{array}{l}\text { - Vanaf } 2018 \text { tellen heggen en houtwallen (en } \\
\text { bomen in rijen) voortaan mee tot een breedte }\end{array}$ & $\begin{array}{l}\text { Ingetekende werkelijk } \\
\text { oppervlakte telt mee als EA }\end{array}$ \\
\hline
\end{tabular}




\begin{tabular}{|c|c|c|c|}
\hline \multirow[t]{2}{*}{ Type EA } & $\begin{array}{l}\text { Wegings- } \\
\text { factor }\end{array}$ & Voorwaarden & Toegestane soorten \\
\hline & & $\begin{array}{l}\text { van maximaal } 10 \mathrm{~m} \text { en met een } \\
\text { standaardoppervlakte van } 5 \mathrm{~m}^{2} \text { per meter } \\
\text { lengte. }\end{array}$ & \\
\hline $\begin{array}{l}\text { Bomen in rij/ } \\
\text { Windhaag }\end{array}$ & 2 & $\begin{array}{l}\text { - Kruindiameter min. } 4 \mathrm{~m} \text {. } \\
\text { - Tussen de kruinen niet meer dan } 5 \mathrm{~m} \text {. } \\
\text { - Windhaag in perceel fruiteelt. } \\
\text { - Vanaf } 2018 \text { tellen bomen in rijen voortaan mee } \\
\text { tot een breedte van maximaal } 10 \mathrm{~m} \text { en met een } \\
\text { standaardoppervlakte van } 5 \mathrm{~m}^{2} \text { per meter } \\
\text { lengte. }\end{array}$ & $\begin{array}{l}\text { Standaardoppervlakte } \\
5 \mathrm{~m}^{2} \text { per } \mathrm{m} \text { lengte }\end{array}$ \\
\hline Geïsoleerde bomen & 1,5 & - Kruindiameter min. 4 m. & $\begin{array}{l}\text { Standaardoppervlakte } \\
20 \mathrm{~m}^{2} \text { per boom }\end{array}$ \\
\hline Knotboom & 1,5 & $\begin{array}{l}\text { - Kruindiameter min. } 4 \mathrm{~m} \text {. } \\
\text { - Knotbomen die voor knotten diameter van } 4 \mathrm{~m} \\
\text { hebben vallen hier ook onder. }\end{array}$ & $\begin{array}{l}\text { Standaardoppervlakte } \\
20 \mathrm{~m}^{2} \text { per boom }\end{array}$ \\
\hline Boomgroepen & 1,5 & $\begin{array}{l}\text { - Overlappende kruinen } \\
\text { Bij boomgroepen tellen struiken of stenen vanaf } \\
2018 \text { ook mee. De maximale oppervlakte die } \\
\text { voor boomgroepen inclusief bomen en stenen } \\
\text { meetelt, blijt } 0,3 \text { ha. }\end{array}$ & $\begin{array}{l}\text { Ingetekende werkelijk } \\
\text { oppervlakte telt mee als EA }\end{array}$ \\
\hline
\end{tabular}




\section{Bijlage 3 Overzicht output- en resultaatindicatoren voor monitoring vergroening in GLB}

Tabel 1 Overzicht van de aanvullingen op de outputindicatoren van het GTEK voor nationale invulling vergroening (uit Van Doorn et al., 2015).

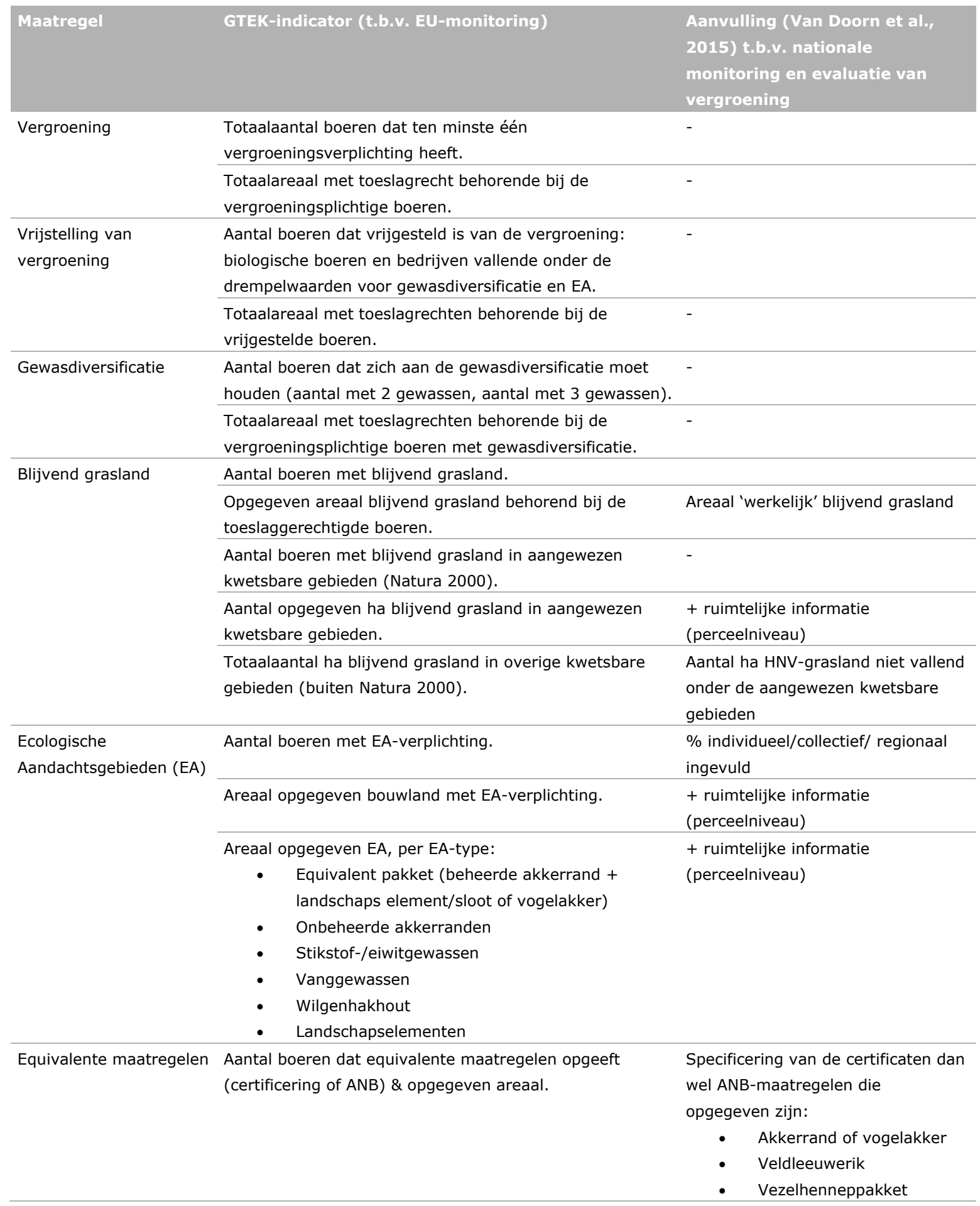


Tabel 2: Overzicht van de aanvullingen op de resultaatindicatoren van het GTEK voor nationale invulling vergroening (uit Van Doorn et al., 2015).

\begin{tabular}{|c|c|c|c|}
\hline & \multicolumn{3}{|l|}{ Resultaatindicatoren } \\
\hline & Onderdeel & $\begin{array}{l}\text { GTEK-indicator (t.b.v. EU- } \\
\text { monitoring) }\end{array}$ & $\begin{array}{l}\text { Aanvullingen t.b.v. nationale } \\
\text { M\&E }\end{array}$ \\
\hline \multirow[t]{4}{*}{$\begin{array}{l}\text { Levering van publieke } \\
\text { diensten, mitigatie van } \\
\text { klimaatverandering }\end{array}$} & \multirow[t]{2}{*}{ Gewasdiversificatie } & $\begin{array}{l}\text { Gemiddeld aantal gewassen } \\
\text { op bedrijfsniveau }\end{array}$ & $\begin{array}{l}\text { Specificatie van gewassen }+ \\
\text { ruimtelijke informatie, onderscheid } \\
\text { naar bedrijven met en bedrijven } \\
\text { zonder vergroeningsmaatregelen }\end{array}$ \\
\hline & & $\begin{array}{l}\text { Gemiddeld aantal gewassen } \\
\text { op regionaal niveau (NUTS2) }\end{array}$ & $\begin{array}{l}\text { Ruimtelijke informatie op PC4- } \\
\text { niveau }\end{array}$ \\
\hline & Blijvend grasland & $\begin{array}{l}\text { Aandeel blijvend grasland op } \\
\text { het totaalareaal } \\
\text { landbouwgrond }\end{array}$ & $\begin{array}{l}\text { Areaal 'werkelijk' blijvend grasland } \\
\text { ruimtelijke informatie (ha of KM2) }\end{array}$ \\
\hline & $\begin{array}{l}\text { Broeikasgasemissies van } \\
\text { landbouwgrond }\end{array}$ & $\begin{array}{l}\text { Jaarlijkse emissies van } \mathrm{CO}_{2} \text {, } \\
\mathrm{CH}_{4} \text { en } \mathrm{N}_{2} \mathrm{O} \text { van } \\
\text { landbouwgrond }\end{array}$ & Zie nationale emissieregistratie \\
\hline
\end{tabular}


Wageningen Environmental Research Postbus 47

6700 AA Wageningen

T 0317480700

www.wur.nl/environmental-research

Wageningen Environmental Research Rapport WENR 2963

ISSN 1566-7197
De missie van Wageningen University \& Research is 'To explore the potential of nature to improve the quality of life'. Binnen Wageningen University \& Research bundelen Wageningen University en gespecialiseerde onderzoeksinstituten van Stichting Wageningen Research hun krachten om bij te dragen aan de oplossing van belangrijke vragen in het domein van gezonde voeding en leefomgeving. Met ongeveer 30 vestigingen, 5.000 medewerkers en 10.000 studenten behoort Wageningen University \& Research wereldwijd tot de aansprekende kennisinstellingen binnen haar domein. De integrale benadering van de vraagstukken en de samenwerking tussen verschillende disciplines vormen het hart van de unieke Wageningen aanpak. 



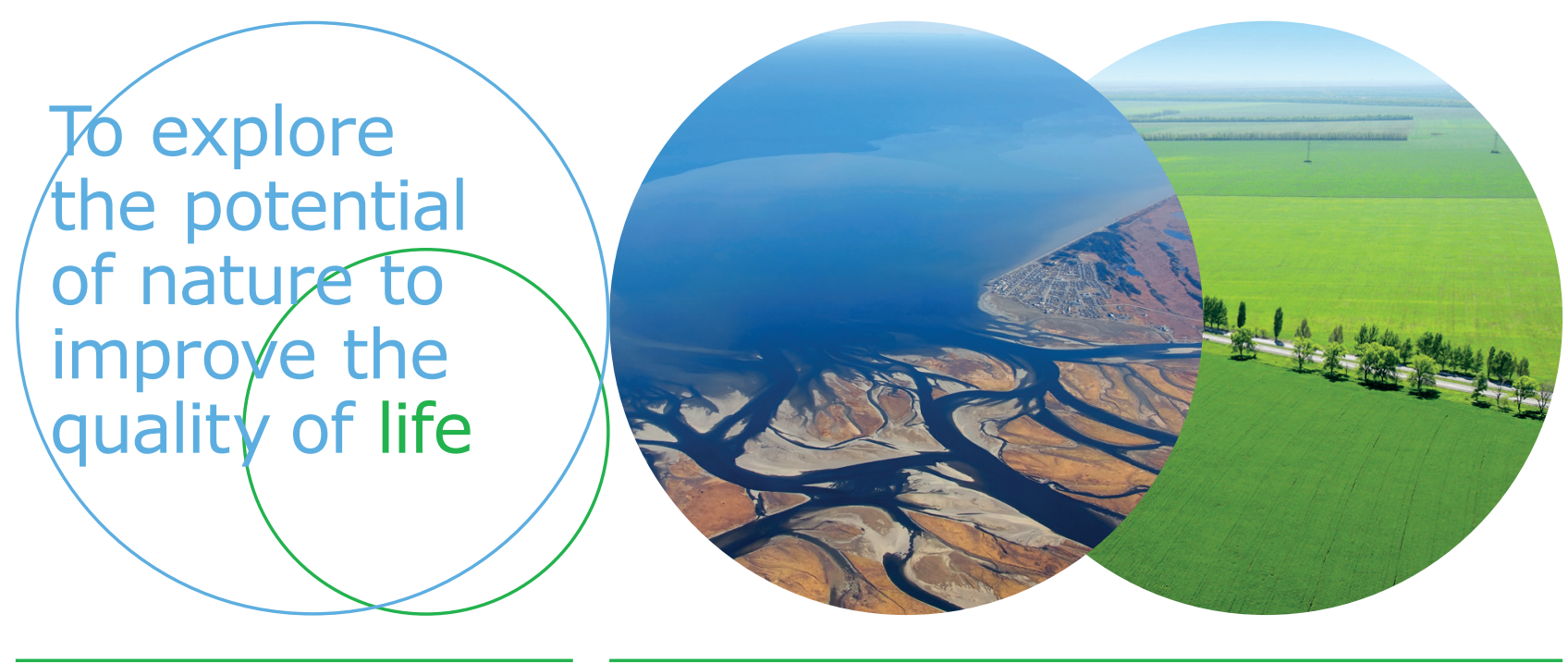

Wageningen Environmental Research Postbus 47

$6700 \mathrm{AB}$ Wageningen

T 317480700

www.wur.nl/environmental-research

Rapport 2963

ISSN 1566-7197
De missie van Wageningen University \& Research is 'To explore the potential of nature to improve the quality of life'. Binnen Wageningen University \& Research bundelen Wageningen University en gespecialiseerde onderzoeksinstituten van Stichting Wageningen Research hun krachten om bij te dragen aan de oplossing van belangrijke vragen in het domein van gezonde voeding en leefomgeving. Met ongeveer 30 vestigingen, 5.000 medewerkers en 10.000 studenten behoort Wageningen University \& Research wereldwijd tot de aansprekende kennisinstellingen binnen haar domein. De integrale benadering van de vraagstukken en de samenwerking tussen verschillende disciplines vormen het hart van de unieke Wageningen aanpak. 